PontIFícIA UNIVERSIDADE CATÓLICA DO RIO DE JANEIRO

\title{
Multiculturalismo: Como Impactam na Cultura Organizacional de Empresas Multinacionais
}

\author{
Isabelle Lima de Azevedo
}

Trabalho de Conclusão de Curso

Centro de CiênCias sociais - CCS

DEPARTAMENTO DE ADMINISTRAÇÃO

Graduação em Administração de Empresas 
Isabelle Lima de Azevedo

\section{Multiculturalismo: Como impactam na cultura organizacional}

Trabalho de Conclusão de Curso

Trabalho de Conclusão de Curso, apresentado ao programa de graduação em Administração da PUC-Rio como requisito parcial para a obtenção do titulo de graduação em Administração.

Orientador(a) : Andrea Gomes Bittencourt 
"Grandeza não é para os escolhidos, a gradeza é para todo mundo que decidir ir atrás dela." (Autor desconhecido) 


\section{Agradecimentos}

Agradeço a PUC-RIO, ao IAG e aos professores que me auxiliaram e me cumpiram com louvor o seu papel, orientando e compartilhando o seu conhecimento para que eu pudesse cada vez mais enriquecer o meu conhecimento intelectual e pessoal. Que sempre estiveram apoiando-me e motivando nos momentos bons e amparando e dando bons conselhos nos momentos ruins.

Agradeço a minha orientadora Andrea Bittencourt, por me orientar e me motivar ao longo deste semestra para que eu conseguisse concluir este projeto e e em esclarecer todas as duvidas que ocorreram ao longo deste percurso.

Gostaria de agradacer especialmente a professora Alessadra Baiochhi por ter me apresentado este tema no quarto período da faculdade e por ter me auxiliado em adapta-lo para estudar no mesmo na área de Organizações. Gostaria de agradecer a professora Patricia Itala que esteve presente ao longo do meu dominio adicional em Empreendedorismo que me auxilou imensamente em me desenvolver pessoalmente e me tornar uma pessoa mais segura e confiante em relação a mim mesma.

Agradeço imensamente ao meu pai que sempre esteve presente na minha formação,não só profissional mas principalmente pessoal, sendo a pessoa que mais me incentivou e comemorou comigo todas as minhas conquistas e sempre apostou em meus sonhos e acima de tudo me ensinou a ser uma pessoa resiliente para que pudesse sempre vencer qualquer acontecimento ruim que possa acontecer na minha vida.A minha mãe que me educou e me criou para que eu me tornasse uma pessoa forte e segura de que sempre conquistaria os meus objetivos, mesmo que passase por momentos ruins ao longo desta caminhada,dedico este trabalho a ela e eu sei que ela estava junto comigo em todos estes momentos. A minha avó que sempre esteve presente na minha vida orando e me protejando de toda e qualquer coisa que possa me acontecer, sempre me colocando para cima quando eu estava desmotivada e me apoiando a tudo. Ao meu avô que mesmo não estando mais aqui sonhou comigo esse momento e onde quer que ele esteja ele estará vendo que eu venci e ele faz parte disso. 
Agradeço imensamente ao meu noivo que ao longo de todos os anos esteve ao meu lado lutando comigo e sempre comemorando minhas conquintas e em algumas situações acreditando mais em mim do que eu mesma, ele que está presente em todas as situações, sendo boas ou ruins e que sempre me joga para cima e me faz sempre olhar para cima com a cabeça erguida e deixando claro que devo ter sempre orgulho da pessoa que me tornei.

Agradeço imensamente a minha amiga e companheira de faculdade Laís Alves,que esteve presente ao longo destes últimos semestres da faculdade assim como ela sempre se fez presente na infancia, sempre me dando força e motivando para que esse trabalho fosse concluido da melhor forma e dividando comigo esse momento de suma importância na minha vida.

Agradeço aos meus amigos Amanda Gomes, Antonio Pedro Bello, Barbara Guedes, Carollini Fernandes, Clarissa Fernandes, Gabriela Pereira, Erida Ribeiro, Ingryd Cerqueira,Thamires Peluzio, Suzana Alves, Julia Rosa, Rachel Guedes e a todos que estiveram comigo neste momento e me apoiaram e me motivaram a concluir esta estapa.

Por fim, agradeço aos 202 participantes da pesquisa quantitativa realizada neste estudo. Muito obrigada por terem reservado um tempo para colaborarem com o meu estudo e terem colaborado para que eu pudesse alcançar minha formatura. 


\section{Resumo}

Azevedo, Isabelle Lima. Bittencourt, Andréa. Multiculturalismo: Como impactam na cultura organizacional. Rio de Janeiro, 2018. p. 51. Trabalho de Conclusão de Curso - Departamento de Administração. Pontifícia Universidade Católica do Rio de Janeiro.

Para trabalhar eficazmente com pessoas de culturas diferentes é preciso compreender a cultura, como ela as moldou e como se adaptar o estilo de gerenciamento a essas diferenças. O presente estudo tem como objetivo descobrir como o multiculturalismo impacta na cultura organizacional em organizações multinacionais ou que sofreram processo de fusão e aquisição. A partir de uma pesquisa quantitativa composta por indivíduos que pertenciam a este cenário, foram extraídos dados relevantes ao estudo e analisados aspectos inerentes a este movimento.

Palavras- chave: Multiculturalismo; Diversidade; Cultura Organizacional; Clima organizacional.

\section{Abstract}

Azevedo, Isabelle Lima. Bittencourt, Andréa. Multiculturalism: As impact on organizational culture. Rio de Janeiro, 2018. p 51. Trabalho de Conclusão de Curso - Departamento de Administração. Pontifícia Universidade Católica do Rio de Janeiro.

To work effectively with people from different cultures need to understand the culture, as she cast and how to adapt the management style of these differences. The present study aims to find out how multiculturalism impacts on organizational culture in multinational organizations or who have been affected by merger and acquisition process. From a quantitative survey consisting of individuals who belonged in this scenario, data relevant to the study were extracted and analyzed aspects inherent to this movement.

Key-words: Multiculturalism; Diversity; Organizational Culture; Organizational climate. 


\section{Sumário}

1 O tema e o problema de estudo 1

1.1. Introdução ao tema e ao problema do estudo 1

1.2. Objetivo do estudo 3

1.3. Objetivos intermediários do estudo 3

1.4. Delimitação e foco do estudo 3

1.5. Justificativa e relevância do estudo 4

2 Revisão de literatura 5

2.1 Multiculturalismo 5

2.2 Cultura Organizacional 6

2.2.1 Mudança Organizacional 8

2.2.2 Dimensões Culturais - Tipologia de Hofstede 9

$\begin{array}{ll}2.3 \text { Clima Organizacional } & 10\end{array}$

2.4. Diversidade Cultural 12

$\begin{array}{ll}\text { 2.5. Organizações Multiculturais } & 13\end{array}$

3 Metodologia de Pesquisa $\quad 15$

$\begin{array}{ll}3.1 \text { Problema } & 16\end{array}$

$\begin{array}{ll}3.2 \text { Hipóteses } & 17\end{array}$

3.3 Pesquisa 18

3.4 Informações Selecionadas para a Realização da Coleta de Dados 19

3.5 Instrumentos Utilizados para a Coleta de Dados 21

$\begin{array}{lll}3.6 & \text { Limitações do Estudo } & 21\end{array}$

4 Análise e Intepratação dos Resultados 22

4.1 Descrição e Análises do Resultado 22

5 Conclusão 38

6 Referências Bibliográficas 41 


\section{Lista de figuras}

Figura 1 Padrão explicativo de como a cultura emerge …................................ 7

Figura 2 - Fases do Processo de Mudança .................................................. 8

Figura 3 - Porcentagem de respondentes que já trabalharam ou trabalham em empresas Multinacionais ou que sofreram processo de Fusão e Aquisição.

Figura 4 - Tipos de Empresas .............................................................. 23

Figura 5 - Tabulação em relação as áreas dos colaboradores e níveis dentro da



Figura 6 - Faixa etária em relação ao gênero ................................................ 25

Figura 7 - Escolaridade em relação ao cargo ocupado.................................... 25

Figura 8 - Principais pontos da diferença cultura .......................................... 27

Figura 9 - Diversidade presente nas organizações....................................... 28

Figura 10 - Percepção de como a organização lida coma diversidade .............. 29

Figura 11 - Beneficios da diversidade nas organizações ................................. 30

Figura 12 - Beneficios da diversidade nas organizações ................................ 30

Figura 13 - Ações do departamento de Recursos Humanos ............................. 31

Figura 14 - Nivel de estímulo do departamento de Recursos Humanos para os colaboradores opinarem ................................................................... 32

Figura 15 - Percepção em relação as medidas tomadas quando ocorrem mudanças nas organizações .............................................................. 33

Figura 16 - Comunicados de mudanças nas organizações .............................. 34

Figura 17 - Impactos na cultura pessoal...................................................... 35

Figura 18 - Impactos na cultura organizacional ......................................... 36 
Figura 19 - Pontos positivos em relação a cultura do país de origem da



Figura 20 - Pontos positivos em relação a nossa cultura................................. 37 


\section{O tema e o problema de estudo}

\subsection{Introdução ao tema e ao problema do estudo}

Segundo Fellows (2004) na sociedade atual, em que a gestão do conhecimento adquire importância cada vez maior, as organizações, para obter vantagens competitivas, procuram utilizar o conhecimento existente em suas filiais, dispersas geográfica e culturalmente no mundo. No entanto, apesar das mudanças no contingente de mão-de-obra resultantes da globalização, da comunicação imediata entre nações, da grande presença de imigrantes nos diversos países, da miscigenação dos povos e da crescente demanda de mãode-obra, o tema diversidade cultural ainda é pouco explorado pelas organizações

O multiculturalismo é algo visto desde os primordes do mundo, visto que países eram colonizados por outros e com isso sempre ocorria este processo. No Brasil, principalmente, esse processo sempre foi algo muito comum, pois é um país que sempre recebe inúmeros imigrantes e com o passar dos tempos a imagem só se tornou mais consistente em relação ao bom recebimento de imigrantes o que os influencia a virem para o país de uma maneira mais frequente e consistente.

Com a globalização, a mudança de país é algo coriqueiro e, com isso, a maior integração entre as culturas se tornou algo comum. Como consequência dessa integração, as pessoas precisam se adaptar a essa nova realidade e também precisam iniciar a vida profissional no novo país em que se está morando. O crescimento das empresas multinacionais se tornaram mais comuns para as pessoas que já trabalham nessas organizações e são transferidas para outro país, assim como para quem pertence ao país que está recebendo uma filial da empresa em questão.

Segundo Subbarao (1995), nota-se que a diversidade da força de trabalho é um fenômeno internacional, presente nos países desenvolvidos ou em desenvolvimento. Há diversos aspectos a serem considerados ao se pensar no que significa diversidade: sexo, idade, grau de instrução, grupo étnico, religião, origem, raça e língua. Mamman (1995) e Nilson (1997) assumem também que o 
conceito de diversidade cultural inclui não somente a raça e o sexo, mas também grupos étnicos, região de origem, idade, etc.

Com a diversidade sendo vista como algo tradicionalmente brasileira quando se trata de aspectos culturais é possivel identificar que nas organizações essas tendências estão impactando diretamente as empresas brasileiras, visto que, com o potencial do país, muitas empresas internacionais migraram para o Brasil, alocando filiais em território brasileiro.

Segundo a revista Veja, em fevereiro de 2015 , mais de $80 \%$ das questões de negócios não foram fechados devido a diversidade multicultural entre clientes e fornecedores. Sendo assim, se torna visível o quão importante é, para as organizações e os colaboradores, a melhoria na integração de suas culturas tendo como objetivo mitigar os riscos que podem ocorrer quando se trata de um bom convívio organicacional como também para promover novos negócios e/ou parcerias.

Segundo Jones e George (2011), é importante trabalhar o tema da diversidade dentro da organização, pois levando em consideração este fator, como sendo um recurso positivo para a organização, onde a diversidade pode vir a se tornar um subsídio vantajoso e competitivo, auxiliando ao fornecimento de serviços e produtos com uma melhor qualidade aos clientes. Pois com esta cultura presente e forte dentro da organização, a mesma será capaz de entender melhor o seu cliente e o mercado diversificado em que está inserida, pois atualmente o mercado demanda das empresas posições diferentes para atender ao mercado-alvo da mesma, visto que o mercado está demandando produtos mais personallizados e diferenciados para atender a públicos globais.

Segundo Barbosa (2004), nas últimas décadas o termo "cultura" passou a ser associado no âmbito das organizações a um conjunto de novos conceitos relacionados entre si que expandiu em várias direções seus significados, interligando questões que anteriormente não eram discutidas, gerando novas implicações de ordem prática e estabelecendo novas redes semânticas. Levando em conta estas novas questões que são consideradas pelas organizacções, este estudo pretende medir como os valores culturais de seus colaboradores impactam na cultura organizacional e como os colaboradores se sentem impactados pela cultura organizacional, levantando em conta a seguinte questão: Como os valores multiculturais impactam na cultura organizacional e como os colaboradores se sentem impactados? 


\subsection{Objetivo do estudo}

Este estudo teve como principal objetivo analisar os principais impactos gerados pelos processos de multiculturalismo em relação à cultura organizacional das empresas multinacionais que possuem filiais do Rio de Janeiro, a fim de avaliar quais foram os pontos positivos e negativos destes processos e como as organizações podem tomar medidas para melhorar os pontos negativos encontrados.

\subsection{Objetivos intermediários do estudo}

Para se atingir o objetivo final proposto esse estudo prevê, como objetivos intermediários a serem alcançados:

$\checkmark$ Identificar quais foram os principais pontos que mais impactaram a cultura organinacional;

$\checkmark$ Investigar como esses impactos podem ser menos sentidos pelas organizações;

$\checkmark$ Investigar como ter um melhor desempenho e resultado sobre esse processo de multiculturalismo;

$\checkmark$ Analisar quais os pontos mais releventes devem ser levados em consideração para que o processo tenha melhores resultados, caso o mesmo seja negativo;

$\checkmark$ Intensificar os pontos positivos gerados pelo processo em questão;

$\checkmark$ Propor soluções caso os impactos gerados sejam negativos;

$\checkmark$ Propor medidas para fortalecer os pontos positivos que o processo gerou para as empresas.

\subsection{Delimitação e foco do estudo}

Este estudo foi delimitado às empresas do estado do Rio de Janeiro que passaram por processos de multiculturalismo nos últimos cinco anos.

Este estudo tem como variáveis os impactos causados pela mudança da cultura organizacional gerada pelo processo de multiculturalismo, como as empresas devem proceder caso o processo cause impactos negativos e como 
devem proceder para fortalecer e intensificar os impactos positivos gerados pelo processo em questão.

O foco do estudo se deu por conta da globalização que vem se fortalecendo cada vez mais nos últimos anos e os processos de multiculturalização cada vez mais frequentes nas organizações de todo o mundo. No Brasil principalmente por ter já um histórico de ser um excelente anfitrião para os imigrantes, esse processo se torna mais forte e frequente no país.

\subsection{Justificativa e relevância do estudo}

As informações que este estudo pretende produzir se mostram interessantes para a área de Recursos Humanos $(\mathrm{RH})$ das empresas em questão, pois com as informações geradas neste estudo o $\mathrm{RH}$ conseguirá identificar os pontos que estão sendo mostrados como postivos e negativos por seus colaboradores e, assim, conseguir criar medidas para solucionar os pontos negativos e intensificar os pontos positivos para que o processo de fusão e aquisição tenha um resultado mais eficiente e satisfatório para a organização em todas as áreas da organização com o objetivo de mitigar as incertezas geradas por esse processo.

Os resultados alcançados também poderão ser úteis para as futuras empresas que pretendem passar por processos de multiculturalismo, já que este processo gera inúmeras incertezas e riscos para as empresas que se propõem em fazer essa mudança. Por mais que não se tenha um modelo a ser seguido, já que cada empresa dispõe de uma cultura organizacional, os impactos gerados podem ser semelhantes e as propostas para solucionar podem ser tidas como inspiração para que alguma atitude seja tomada.

Além disso, esse estudo é de relevância para o mercado onde as empresas em questão estão inseridas já que, com a demanda crescente deste processo, é necessário que as empresas estejam sempre prontas e alinhadas com o mercado que estão inseridas para que não percam oportunidades relevantes que impedirão um maior crescimento. 


\section{Revisão de literatura}

Neste capítulo são apresentados e discutidos aspectos conceituais e estudos relacionados ao tema e estudo em investigação e que servirão de base para a análise realizada.

Os conceitos apresentados se referem aos processos de multiculturalismo, cultura organizacional e mudanças organizacionais.

\subsection{Multiculturalismo}

A cultura é difícil de mudar, principalmente em um nível mais profundo, com valores e pressuposições básicas. O multiculturalismo significa a existência de muitos e diferentes elementos e fatores culturais trazidos às organizações por pessoas provavelmente de diferentes culturas e que coexistam e florescem dentro das organizações. (CHIAVENATO, 2005, p. 165).

"As metas organizacionais que são diretamente atingidas pelo bom gerenciamento da diversidade referem-se à responsabilidade moral, ética e social da organização, suas obrigações legais e o aumento do desempenho econômico" (COX, 1994 apud Zanelli, 2009).

Com o mundo e o mercado cada vez mais globalizado as organizações atualmente precisam saber lidar com a maior integração de cultura, visto que não se tem, na maior parte das organizações, colaboradores que possuem a mesma cultura ou nacionalidade. Com isso a organização precisa criar formas de integrar de uma forma que agrege maior valor competitivo para a mesma e com isso consiga trazer beneficios para a organização e com isso pode acarretar melhores resultados futuros.

O processo em questão é uma teoria largamente estudada por inúmeros autores, dando maior força a esse fato e mostrando para as organizações o quão relevante é passar para os seus colaboradores que a empresa se preocupa com essa integração e como pode trazer beneficios financeiros e principalmente no ambito pessoal da organização.

Segundo Kymlicka,1997,2001;Taylor, 1994, multiculturalismo e interculturalismo são conceitos que procuram dar conta desta questão. 0 
primeiro surgiu em meados dos anos setenta, no Canadá e na Austrália, e foi utilizado como instrumento discursivo para forçar os governos destes países a desenvolverem políticas mais adequadas às minorias culturais e aos pluralismo étnico que os caracterizavam.Pelo termo multiculturalismo, buscava-se superar políticas assimilacionalistas, moralmente duvidosas, em prol da manutenção das identidades culturais distintas das minorias, para que estas pudessem ter orgulho de sua cultura e,ao mesmo tempo, a sensação de pertencimento ao todo. Como doutrina política, o multiculturalismo defendia políticas de reconhecimento dos direitos, das identidades culturais das minorias e do valor da diversidade cultural.

Entretanto, a partir da década de 1980, com o avanço da globalização e das pressões pela implementação da agenda social, oriundas dos movimentos civis nas empresas (Barbosa, 2002), o contato intercultural, até então restrito aos segmentos mais elevados das organizações e aos expatriados, expandiu-se e rotinizou-se, ao mesmo tempo em que a ideia de diversidade e diferença passou a ser percebida e transformada em uma tecnologia gerencial. Trabalhar em e com times "multiculturais" e operar em mercados culturalmente diversos passou a ser parte integrante do cotidiano organizacional, um diferencial competitivo para jovens gerentes e uma exigência básica para qualquer líder organizacional, conforme PARKE, (1995).

Com esse novo contexto é possivel identificar que é de suma importancia para as organizações atuais darem importancia a esse processo que está presente no mundo globalizado e cada vez mais frequente nas organizações mordernas.

\subsection{Cultura Organizacional}

Segundo Vecchio (2015) pode-se definir cultura organizacional como os valores e normas compartilhados que existem em uma organização e são ensinados aos novos empregados. Essa definição sugere que a cultura organizacional envolve crenças e sentimentos comuns, comportamento regular e um processo histórico para a transmissão de valores e normas. O conceito de cultura organizacional, apesar de sua falta de precisão, é amplamente adotado em círculos gerenciais, algumas vezes como explicações abragentes e adequadas para justificar o motivo pelo qual as coisas acontecem ou deixam de 
ocorrer de determinada maneira em uma empresa, como por exemplo: "É a maneira como fazemos as coisas aqui - é parte de nossa cultura."

Segundo Chiavenato (2010) a cultura equivale ao modo de vida das organizações em todos os seus aspectos, como idéias, crenças, costumes, regras, técnicas, etc. A cultura organizacional ou cultura corporativa é o conjunto de hábitos e crenças, estabelecidos por normas, valores, atitudes e expectativas, compartilhados por todos os membros da organização.

Segundo Zanelli (2007) uma cultura organizacional emerge quando os participantes passam a compartilhar conhecimentos e pressupostos de como descobrir ou desenvolver modos de lidar com questões de adaptação externa e integração interna. Este conceito está melhor explicado na figura abaixo.

\begin{tabular}{|c|c|c|c|}
\hline $\begin{array}{l}\text { Fundadores e } \\
\text { Colaboradores }\end{array}$ & $\begin{array}{l}\text { Comportamento } \\
\text { organizacional }\end{array}$ & Resultados & Cultura \\
\hline $\begin{array}{l}\text { Os pioneiros, aliados ou } \\
\text { não a colaboradores } \\
\text { desenvolvem e tentam } \\
\text { implementar uma visão } \\
\text { compartilhada e uma } \\
\text { estratégia para o } \\
\text { empreendimento. }\end{array}$ & $\begin{array}{l}\text { A implementação é } \\
\text { bem sucedida. Os } \\
\text { funcionários se } \\
\text { comportam de acordo } \\
\text { com os valores } \\
\text { compartilhados e com } \\
\text { a estratégia do } \\
\text { empreendimento. }\end{array}$ & $\begin{array}{l}\text { A organização baseia } \\
\text { o seu sucesso nos } \\
\text { resultados financeiros } \\
\text { e nos indicadores de } \\
\text { desempenho. }\end{array}$ & $\begin{array}{l}\text { A cultura emergente } \\
\text { reflete a visão, estratégia } \\
\text { e as experiências das } \\
\text { pessoas na organização. } \\
\text { Essa cultura descreve } \\
\text { comportamentos que são } \\
\text { aceitáveis e inaceitáveis e } \\
\text { as tradições que serão } \\
\text { mantidas. }\end{array}$ \\
\hline
\end{tabular}

Figura 1 Padrão explicativo de como a cultura emerge

Fonte: Psicologia, organizações e trabalho no Brasil (Zanelli, 2007, cap 13, pag 427)

A cultura organizacional é vista como item que mais influência, pois age tanto como elemento de comunicação interna como também de articulação gerencial das empresas. A forma como a mesma é interpretada pelos colaboradores da empresa caracteriza o clima organizacional, podendo ter intepretações boas ou ruins além de ser influenciador direto da motivação das equipes e do grau de satisfação sobre a mesma. Além de também, por meio da pesquisa de clima organizacional ser possivel identificar falhas e desenvolver melhorias para a organização e com isso fazer desenvolver melhorias e concertar falhas no processo de fusão e aquisição, bem como possibilita identificar as mudanças que o processo provoca na organização e como analisalas da forma mais eficaz para tomar medidas mais assertivas, de forma a 
executar as tarefas e o desenvolvimento de novas ideias geradas pelo processo de multiculturalismo.

\subsubsection{Mudança Organizacional}

Segundo Lewin (apud Chiavenato 2010) a mudança é um aspecto essencial da criatividade e inovação nas organizações de hoje. A mudança está em toda parte: nas organizações, nas pessoas, nos clientes, nos produtos e serviços, na tecnologia, no tempo e no clima. A mudança representa a principal característica dos tempos modernos. A mudança envolve transformação, interrupção, pertubação, ruptura, dependendo da sua intensidade. Ela constitui um processo composto por três etapas: descongelamento, mudança e recongelamento.

Estas etapas são melhor explicadas na figura abaixo.

\section{PROCESSO DE MUDANÇA}

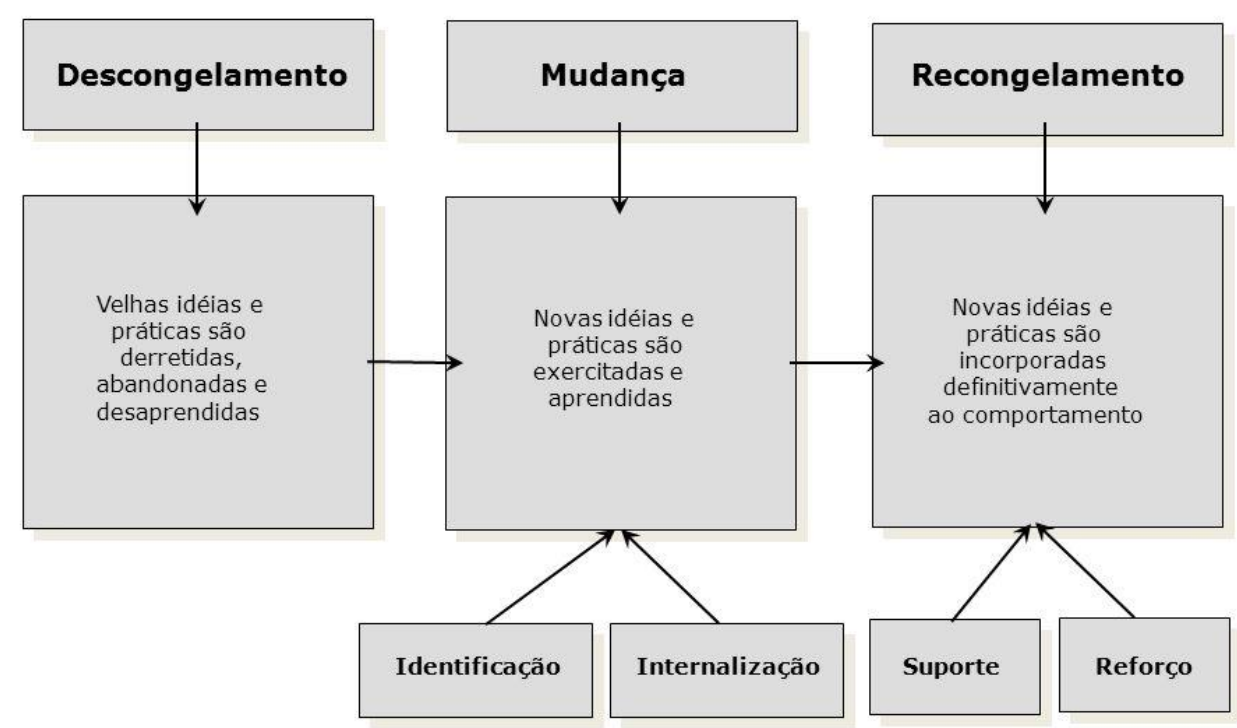

Figura 2 - Fases do Processo de Mudança

Fonte: Gestão de pessoas (Chiavenato, 2010, cap 13, p.407)

É possivel identificar que o processo de mudança organizacional é um item crucial para que os colaboradores entendam que a empresa está começando com uma nova identidade e que passar por esse processo é algo que a longo 
prazo não será mais percebido, mas que a curto prazo pode causar um choque muito grande para os colaboradores.

Quando a empresa não consegue passar por esse processo com um saldo positivo no final possivelmente terá problemas em relação a cultura e no clima organizacional, visto que esse processo de multiculturalismo gera impactos de curto prazo quanto a situações internas mas também pode gerar impactos a longo prazo, já que as organizações que não tem um bom clima organizacional acabam gerando uma desmotivação nos seus colaboradores e com isso pode impactar negativamente na geração de valor financeiro da empresa pois pode se perder negócios por imcompatibilidade nos valores das empresas e dos seus futuros clientes.

\subsubsection{Dimensões Culturais - Tipologia de Hofstede}

Segundo Hedler e Lima (2003) em busca de estabelecer padrões universais e de investigar diferenças entre culturas destaca-se o trabalho realizado por Hofstede (1980). Esse trabalho estabelece uma teoria de gerenciamento cultural por meio de quatro dimensões bipolares que podem descrever diferenças culturais entre países. Essas dimensões são conhecidas como "distância do poder", "individualismo versus coletivismo", "masculinidade versus feminilidade" e "aversão à incerteza". Nove anos após o primeiro estudo, foi identificado uma quinta dimensão, o "confucionismo". As dimensões desta teoria estão melhor explicadas abaixo.

$\checkmark$ Distância do Poder: demonstra até que ponto as pessoas sentem que têm de tomar conta de si próprias, das suas famílias ou organizações a que pertencem ou seja, esta dimensão mostra que uma sociedade é uma rede social sem relação entre os indivíduos, na qual cada um demonstra interessar-se apenas por si mesmo, ou se ela oferece um papel social fechado no qual os indivíduos se dividem entre membros e não membros de grupos e supõem que o grupo ao qual pertencem os proteja.

$\checkmark$ Individualismo x Coletivismo: de que forma as pessoas sentem que têm de tomar conta de si, das suas famílias ou organizações a que pertencem, sendo assim, esta dimensão deixa claro se uma sociedade é uma rede social sem relação entre os indivíduos, na qual cada um é suposto interessar-se apenas por si mesmo, ou se ela oferece um tecido social fechado no qual os indivíduos se 
dividem entre membros e não membros de grupos e esperam que o grupo ao qual pertencem os proteja.

$\checkmark$ Masculinidade versus feminilidade: demonstra até que ponto a cultura é vista como dominante, assertiva e demonstra uma maior aquisição de coisas versus uma cultura que é mais conducente das pessoas, sentimentos e qualidade de vida. Refere-se também como o sexo é visto e determinante perante os papéis dos homens e das mulheres na sociedade.

$\checkmark$ Evitar a incerteza: Está dimensão como definição o grau de ameaça percebido por membros de uma cultura em situações incertas ou desconhecidas, ou seja, reflecte o sentimento de desconforto que as pessoas sentem ou a insegurança com riscos, caos e situações não estruturadas.

$\checkmark$ Confucionismo - indica que medida uma sociedade tem baseado as suas tradições sobre os acontecimentos do passado ou do presente, sobre os benefícios apresentados ou ainda sobre o que é desejável para o futuro.

A partir desta teoria é possivel identificar que o cenário onde a organização está inserida impacta diretamente na mesma, visto que por mais que o colaborador esteja fora do seu pais de origem ou a empresa esteja fora do mesmo as situações geradas pela rotina interna da organização pode porporcionar aos funcionarios diferentes comportamentos e assim o mesmo pode seguir ou não a cultura que já possui ou não. Visto isso é de suma importancia a organização saber lidar com essa possibilidade de choque cultura que pode ocorrer de forma positiva ou negativa, já que isso depende de cada pessoa que esteja passando pela situação em questão.

\subsection{Clima Organizacional}

Segundo Robbins (2010), clima organizacional refere-se às percepções comuns que os funcionários de uma organização têm em relação à empresa e ao ambiente de trabalho. 
O clima organizacional refere-se ao que as pessoas acreditam que existe e que está acontecendo no ambiente da organização em determinado momento (Coda, 1998).

Champion (1988) define clima organizacional como sendo as impressões gerais ou percepções dos empregados em relação ao seu ambiente de trabalho. Embora nem todos os indivíduos tenham a mesma opinião (pois não têm a mesma percepção), o clima reflete o comportamento organizacional, isto é, atributos específicos de uma organização, seus valores, crenças e atitudes que afetam a maneira pela qual as pessoas ou grupos se relacionam no ambiente de trabalho.

Chiavenato (2000, p. 305) define o clima organizacional como sendo "a qualidade ou propriedade do ambiente organizacional que é percebida ou experimentada pelos participantes da empresa e que influencia o seu comportamento".

Para Schneider \& Snyder 1975 (apud SÁ LEITÃO, 1995, p. 28), "o clima organizacional é mais adequadamente conceitualizado como uma percepção sumária que os indivíduos têm de (ou sobre) uma organização".

Para Bowditch (1997, p. 189), o clima organizacional:

(...) é uma percepção resumida da atmosfera e do ambiente da organização, e tem implicações na satisfação com o trabalho e a organização, no desempenho, nos padrões de interação em grupos, e nos comportamentos de afastamento (por exemplo, absenteísmo, rotatividade).

Conforme os autores acima afimam é possivel notar que o clima organizacional faz parte da cultura organizacional, porém existem diferenças notaveis já que o clima é medido por um recorte de tempo dentro da organização, geralmente medido por uma pesquisa com os funcionários e em contra partida a cultura é algo que a empresa passa para o seu colaborar ao longo da vida do mesmo dentro da organização, já que a mesma contem os valores e diretrizes da organização.

O clima auxilia a identificar se os colaboradores estão motivados e se estão se sentindo atendidos pelo que a empresa proporciona para o mesmo, tendo um clima favoravel e harmonico existem uma tendencia de que a cultura se fortaleça cada vez mais além de atender os funcionarios da forma que o mesmo espera.

A cultura e o clima organizacional são diretamente ligados dentro da organização, já que os mesmos medem diretamente a percepção e como os 
funcionarios se sente em relação ao que a organização os proporciona. Visto isso é necessário ter uma cultura bem dissiminada dentro da mesma para que o clima se mantenha harmonico e agradavel, visto isso a mistura e adaptação a novas culturas impactam diretamente nessas duas vertentes, já que se o clima for entendido como um aspecto ruim dentro da organização o mesmo irá impactar diretamente na ampliação do entendimento da cultura da mesma e assim irá gerar impactos negativos a curto e longo prazo dentro da organização.

\subsection{Diversidade Cultural}

Hofstede (1991, apud PAIVA, 2012) diz que os contatos interculturais geralmente são acompanhados de processos psicológicos e sociais. Normalmente o estrangeiro sofre um "choque cultural". O processo de aculturação, pelo qual passam os expatriados e emigrantes que têm uma missão num país estrangeiro, tem quatro fases: Fase 1: euforia; Fase 2: choque cultural; Fase 3: aculturação; Fase 4: estabilidade mental.

Segundo Hofstede (1991, apud PAIVA,2012), a cultura anfitriã também passa por um ciclo de reações psicológicas: Fase 1: curiosidade; Fase 2: etnocentrismo (avaliar o visitante segundo o critério da sua própria cultura); Fase 3: policentrismo (aplicar critérios diferentes a pessoas diferentes). É o início do bi ou multiculturalismo. O policentrismo pode conduzir à xenofilia (convicção de que na cultura do estrangeiro tudo é melhor). Nem o etnocentrismo nem a xenofilia são saudáveis para a cooperação intercultural. E também perceber os membros do outro grupo não como indivíduos, mas como estereótipos.

Segundo Srour (2005, apud PAIVA,2012), tudo aquilo que foi inculcado nos indivíduos é reconhecido por eles como fatos naturais e normais, e quaisquer outras maneiras de ser lhes parecem exóticas ou aberrantes. A tendência de toda coletividade é considerar o próprio modo de vida como o mais sensato e o mais correto, e isso leva ao etnocentrismo (ótica exclusivista de uma cultura). A diversidade dos costumes exige o relativismo cultural, que exige humildade intelectual. Nas organizações, a cultura impregna todas as práticas e constitui um conjunto definido de saberes, formando um sistema de significações que procura unir todos os membros em torno dos mesmos objetivos. A cultura organizacional, que especifica a identidade da organização, é construída ao longo do tempo e serve de chave para distinguir diferentes coletividades.

Conforme os autores deixam claro, é de suma importância uma organização moderna se preocupar com a diversidade cultural que existe dentro 
da mesma, visto que com o avanço da globalização esse movimento se torna cada vez mais frequente com isso são gerados impactos tanto para as organizações como também para os colaboradores que precisam aprender a lidar com uma cultura nova, seja quando muda país ou quando ingressa em uma organização multinacional com várias culturas dentro da mesma.

Sendo assim esse movimento gera inúmeros desafios para a área de Recursos Humanos das organizações para que desenvolvam mecanismos para que consigam identificar e minimizar os impactos negativos que possam ser gerados com essa integração e para que se intensifiquem os resultados positivos da mesma, já que essa maior integração impacta diretamente na cultura e clima das organizações.

\subsection{Organizações Multiculturais}

Canen e Canen (2005, apud PAIVA,2012) dizem que as instituições, seus pressupostos e suas dinâmicas são construções de grupos humanos, em sociedades específicas, inspiradas por valores culturais singulares, intimamente ligados a interesses econômicos e políticos. Entende-se por organização multicultural aquela em que trabalham indivíduos de diferentes perspectivas culturais e que articula suas atividades a esta pluralidade, levando-a em consideração no próprio processo de construção da cultura organizacional, tendo como consequência melhor desempenho empresarial. Uma organização multicultural deve incentivar e valorizar as diferenças culturais.

Segundo PAIVA (2012), nos tempos atuais, os movimentos culturais, raciais, feministas e outros têm trazido à tona a multiplicidade de identidades dentro de uma nação. As organizações lidam com culturas diversas, dentro ou fora do espaço nacional, o que demanda uma análise em uma perspectiva que vai além do caráter multinacional das organizações, percebendo-as como organizações multiculturais.

Robbins (2004, apud PAIVA,2012) explica que as diferenças nacionais características da cultura de uma nação - têm de ser levadas em consideração para que seja possível prever com mais precisão o comportamento organizacional próprio de cada país. A cultura do país tem maior impacto sobre os funcionários do que a cultura organizacional. Por mais forte que seja a cultura da organização na modelagem do comportamento dos funcionários, a cultura 
nacional sempre será mais influente. O processo de seleção é usado pelas multinacionais para encontrar e contratar candidatos que se ajustem à cultura dominante, mesmo que sejam atípicos em relação aos conterrâneos. A contratação de funcionários cujo perfil não seja parecido com o da maioria dos membros da organização cria o "paradoxo da diversidade", ou seja, a administração quer que os novos funcionários aceitem os valores essenciais da cultura organizacional - caso contrário, eles não se ajustarão nem serão aceitos - mas, ao mesmo tempo, quer reconhecer e apoiar as diferenças que esses trabalhadores carregam quando passam a fazer parte da empresa. Pessoas diferentes são contratadas porque elas levam forças alternativas para o ambiente de trabalho. $O$ desafio para a administração com esse paradoxo é a busca do equilíbrio entre duas metas conflitantes.

Como os autores acima se referem as organizações multiculturais são um desafio enorme para a adminstração, visto que as empresas por mais que busquem um perfil que não entrem em um conflito com a cultura organizacional dentro da mesma não é algo interessante ter funcionarios com o mesmo perfil na sua totalidade, com isso é necessário contratar funcionarios que sejam diferentes para que sejam percebidos pontos a serem melhorados e mudanças que se fazem necessárias para que a organização evolua e se desenvolva sempre pensando à frente do tempo e se adaptando as novas mudanças que o mercado vai propor. Sendo assim organizações multiculturais se fazem muito importante dentro do ambito da globalização, já que com as organizações mais conscientes em relação a esse aspecto a mesma saberá lidar de melhor forma com as tensões geradas por esse movimento e principalmente saberão lidar com os aspectos positivos ligados a esse processo e assim agregar os pontos positivos a cultura da organização e do clima para tornar as mesmas mais fortes a longo prazo e atender de melhor forma os colaboradores. 


\title{
3 Metodologia de Pesquisa
}

Este capítulo busca explicar como a pesquisa deste estudo será efetivamente elaborada. Segundo Gil (apud SILVA \& MENEZES, 2000), para que se possa desenvolver uma pesquisa científica, é necessário que haja uma metodologia que sirva como um caminho a ser percorrido, de forma a não se perder por trilhos que não levam ao destino.

Segundo Richardson et al (1995), método em pesquisa significa a escolha de procedimentos sistemáticos para a descrição e explicação de fenômenos. Para se determinar qual o método de investigação apropriado para a descrição e explicação de fenômenos em pesquisa, faz-se necessário considerar a natureza e o nível de aprofundamento do problema.

Segundo Gil (2002, p. 17), pesquisa é definida como:

\begin{abstract}
Um procedimento racional e sistemático que tem como objetivo proporcionar respostas aos problemas que são propostos (...) e é requerida quando não se dispõe de informação suficiente para responder ao problema, ou então quando a informação disponível se encontra em tal estado de desordem que não possa ser adequadamente relacionada ao problema.
\end{abstract}

Como mostram os autores citados é de suma importancia definir corretamente a pesquisa e o problema que será abordado pela mesma, porém como visto anteriormente, a partir do refenrencial teorico, existem poucas pesquisas que cruzem todas as teorias abordadas no mesmo sobre o problema em questão. Com isso tantos e estatisticas existentes se tornam insuficientes para que se possa chegar a uma conclusão em relação ao problema de pesquisa.

Ainda segundo Gil (2002, p.17), existem razões que definem a realização de uma pesquisa, as mesmas podem ser de ordem intelectual ou prática. "As primeiras decorrem do desejo de conhecer pela própria satisfação de conhecer. As últimas decorrem do desejo de conhecer com vistas a fazer algo de maneira mais eficiente ou eficaz." Tendo em vista os conceitos citados, as razões para a realização do estudo se da tanto pelo ambito intelectual como prático. A razão intelectual se da pela curiosidade e interesse da autora deste estudo em 
conhecer mais profundamente culturas de outros países e os comportamentos dessas pessoas fora do seu país de origem. Já a razão prática se da pelo desejo da autora deste estudo, a partir dos resultados das hipoteses e cruzamento dos mesmos a partir da pesquisa realizada, contribuir para que sejam desenvolvidas práticas mais eficientes e eficazes para a maior inclusão dentro do ambito corporativo.

\subsection{Problema}

Segundo Gil (2002, p. 23), toda pesquisa se inicia de algum tipo de problema, ou indagação. Onde existem cinco tipos de significados para o que pode ser entendido como "problema":

$\checkmark$ Questão matemática proposta para que se lhe dê a solução;

$\checkmark$ Questão não solvida e que é objeto de discussão, em qualquer domínio do conhecimento;

$\checkmark$ Proposta duvidosa que pode ter numerosas soluções;

$\checkmark$ Qualquer questão que dá margem à hesitação ou perplexidade, por ser difícil de explicar ou resolver;

Conflito afetivo que impede ou afeta o equilíbrio psicológico do indivíduo. Tendo em vista os significados propostos pelo autor, o que mais parece ter relação com o problema proposto neste trabalho seria: "qualquer questão que dá margem á hesitação ou perplexidade, por ser difícil de explicar ou resolver."

Conforme visto anteriormente, o problema apresentado trata da validação dos impactos causados nas organizações e na cultura das mesmas a partir da mistura e maior integração das culturas de diferentes países a partir dos funcionarios das mesmas. A ideia é medir o impacto gerado na cultura das organizações a partir da mistura de culturas dos seus funcionarios e também a percepção dos mesmos do impacto que as organizações com culturas diferentes das de origem dos funcionarios causam nos mesmos e com isso ter um diferecionamento de quais medidas seriam mais acertivas para que se mantenham os resultados positivos e quais medidas devem ser tomadas para diminuir os resultados negativos e reverter estes resultados com medidas eficazes e acertivas para a organização e seus colaboradores.

Estra trabalho foi desenvolvido para entender como pessoas com culturas diferentes que ocupam o mesmo ambiente organizacional impactam a cultura que a empresa prega e como as mesmas se sentem impactadas por essa cultura em empresas multinacionais no município do Rio de Janeiro que 
possuam possuam equipes com colaboradores de culturas difentes ou colaboradores que já tenham ido ou convivido com colaboradores de outras filiais em outros países. Os participantes desta pesquisa devem ter, necessariamente, algum tipo de vínculo empregatício ou contratual com qualquer empresa multinacional situada no município do Rio de Janeiro, podendo pertencer a qualquer posição hierárquica do organograma organizacional, desde jovem aprendiz a presidência. Por fim, a pergunta á que se busca uma conclusão é: "Como os valores multiculturais impactam na cultura organizacional e como os colaboradores se sentem impactados?"

\subsection{Hipóteses}

Segundo Gil (2002, p. 31), a construção das hipóteses possibilitam uma solução á pergunta extraída do problema de pesquisa. "A hipótese é a proposição testável que pode vir a ser a solução do problema."

Ainda segundo o autor, as hipóteses podem ser classificadas em quatro categorias:

$\checkmark$ Algumas hipóteses são casuísticas: Há hipóteses que se referem a algo que ocorre em determinado caso; afirmam que um objeto, uma pessoa ou um fato específico tem determinada característica.

$\checkmark$ Algumas hipóteses referem-se à freqüência de acontecimentos: Hipóteses deste tipo são muito freqüentes na pesquisa social. De modo geral, antecipam que determinada característica ocorre com maior ou menor freqüência em determinado grupo, sociedade ou cultura.

$\checkmark$ Algumas hipóteses estabelecem relação de associação entre variáveis: O conceito de variável refere-se a tudo aquilo que pode assumir diferentes valores ou diferentes aspectos, segundo os casos particulares ou as circunstâncias.

$\checkmark$ Algumas hipóteses estabelecem relação de dependência entre duas ou mais variáveis: As hipóteses deste grupo estabelecem que uma variável interfere na outra.

Quanto ao presente estudo foram utilizadas hipóteses pertencentes a todas as categorias apresentadas anteriormente, como seguem: 
$\checkmark$ Empresas multinacionais tentam descareterizar os colaboradores com culturas diferentes para os mesmos seguirem a cultura que a mesma prega;

$\checkmark$ Colaboradores com culturas diferentes não conseguem quebrar a barreira em relação as suas caracteristicas diferentes e com isso não ocorre aproximação e integração;

$\checkmark$ Como a teoria de Multiculturalismo é percebida na prática dentro das organizações;

$\checkmark$ Como a adoção de práticas da teoria do multiculturalismo impactam em organizações que não cumprem integralmente o seu proposito;

$\checkmark$ Colaboradores não se sentem á vontade de expressar as suas opiniões e sentimentos em relação as práticas adotadas pela empresa.

\subsection{Pesquisa}

Segundo Gil (2002, p.41) é usual a classificação com base em seus objetivos gerais. Assim, é possível classificar as pesquisas em três grandes grupos: exploratórias, descritivas e explicativas. Com base na classificação apresentada está pesquisa está enquadrada no grupo de pesquisas descritivas, visto que é desta forma que será melhor mensurado e explicado os resultados obtivos pela mesma.

Segundo Gil (2002,p.42) uma pesquisa descritiva tem como objetivo primordial a descrição das características de determinada população ou fenômeno ou, então, o estabelecimento de relações entre variáveis. Está pesquisa tem como objetivo avaliar a percepção dos funcionarios de empresas multinacionas em relação a cultura organizacional da empresa e como a mesma os afeta pessoalmente e profissionalmente, além de medir o quanto eles percebem que impactam a cultura da organização com a sua cultura pessoal, visto que é muito comum que se tenha nacionalidades diferentes em empresa multinacionais.

Segundo Gil (2010,p.26-27) as pesquisas podem ser classificadas também de acordo com sua finalidade, podendo ser básicas, ao apenas reunir estudos sobre o tema, ou aplicadas, ao integrar estudos sobre o assunto a fim de adquirir conhecimentos que possam ser aplicados e auxiliem em situações específicas. Neste caso a pesquisa em questão está classificada como aplicada, visto que a 
mesma é fundamentada em teorias e estudos passados e tem o intuito de avaliar qual a percepção dos colabores em relação ao impacto do multiculturalismo em relação a cultura organizacional das empresas onde trabalham.

Em relação aos métodos empregados, existem diversas formas de classificação das mesmas. "Para que se possa avaliar a qualidade dos resultados de uma pesquisa, torna-se necessário saber como os dados foram obtidos, bem como os procedimentos adotados em sua análise e interpretação" (ibidem, p. 28). O planejamento adotado para avaliar as hipótes elaboradas desta pesquisa foi o levamento de campo, popularmente conhecido como survey. "Este tipo de pesquisa é realizada a partir do questionamento direto das pessoas cujo comportamento se deseja conhecer ou entender. Algumas de suas principais vantagens são a quantificação de dados, economia, rapidez e conhecimento direto da realidade" (ibidem, p. 36). "Basicamente, procede-se à solicitação de informações a um grupo significativo de pessoas a cerca do problema estudado para, em seguida, mediante análise quantitativa, obterem-se as conclusões correspondentes aos dados coletados" (ibidem, p. 35). As hipóteses que foram estruturadas para esta pesquisa englobam todos os colaboradores de empresas multinacionas ou estrangueiros que trabalhem nas mesmas, com isto a amostra inclui todos os que estejam neste perfil em empresas situadas no Rio de Janeiro, como visto na delimitação do estudo. Com isso através desta pesquisa quantitativa, serão extraídos dados refentes ao tema e às hipótess propostas, a fim de comprovar ou contestar o que foi apresentado como possível verdade.

\subsection{Informações Selecionadas para a Realização da Coleta de Dados}

Este tipo de pesquisa foi estruturada, onde tentou provar ou não as hipoteses propostas, a partir da plataforma Qualtrics, disponibilizada pela Pontifícia Universidade Católica do Rio de Janeiro, e autorizada pela professora e orientadora Andrea Bittencuort. A pesquisa foi aberta no dia 28 de maio, às $17 \mathrm{~h}$ e fechada no dia 06 de junho às $17 \mathrm{~h}$, passando por dez dias completos de divulgação e obtenção de dados.

Ao todo a pesquisa contou com 202 respondentes, onde 170 concluiram a pesquisa até o fim. O questionario é composto de 23 questões multiplaescolha com apenas uma questão aberta aos respondentes. 
No início do questionário são feitas três perguntas a fim de entender e delimitar a pesquisa em questão, para que seja separado respondentes que fazem parte do perfil de respondentes desta pesquisa. A primeira pergunta questiona o respondente se o mesmo já trabalho ou trabalha em alguma empresa multinacional ou que já tenha sofrido fusão e aquisição. Caso a resposta seja negativa o questionario se encerra naquele momento. Caso contrário,quando se tem uma resposta positiva,o que questionario continua com o respondente selecionando especificamente em que tipo de empresa trabalha ou já trabalhou, posteriormente a isso o mesmo responde qual empresa trabalhou ou trabalha.

Após a seleção dos respondentes são feitas perguntas em relação ao nível de atual do mesmo dentro da organização, a sua escolaridade, o cargo que o mesmo desempenha na organização, a área em que ele trabalha e a quanto tempo trabalha na mesma. Posteriormente são seperados mediante a sua faixa etaria e seu gênero. A partir deste levantamento são introduzidas as questões relevantes ao estudo em questão.

Ao longo do levantamento dos dados são feitas perguntas em relação as principais diferenças que o respondente identifica em relação a sua cultura mediante a cultura que a empresa onde o mesmo trabalha apresenta,se a diversidade é algo que está presente na organização, como o mesmo percebe que a empresa lida com essa diversidade, quais as percepções em relação aos impactos gerados pela diversidade na organização, como o mesmo identifica o clima na organização, quais as medidas utilidades pelo setor de Recursos Hurmanos das organizações para integrar colaboradores com culturas diferentes, avaliar qual a percepeção do colaborar em relação a abertura que o departamento de Recursos Humanos passa ao seu colaborar para o mesmo opinar caso não se sinta complamente avontade com algo que aconteça na organização, quais os metodos utilizados pelo departamento de Recursos Humanos das organizações em relação as mudanças que podem ser causadas na organização, como o colaborar sente que é influênciado pela cultura da organização e como o mesmo avalia que influência a cultura organizacional e por fim pedesse que o mesmo aponte quais caracteristicas positivas da cultura do país de origem da organização é percpetivel para o mesmo e quais caracteristicas da sua cultura o mesmo mais aprecia.

O questionario será programado em modelo "survey", utilizando a ferramenta de pesquisa "Qualtrics" disponibilizada pela Pontifícia Universidade 
Católica do Rio de Janeiro a seus alunos de graduação. Após do fechamento desta pesquisa os dados serão analiasados e interpretados a fim de obter resultados, conclusões e sugestões.

\subsection{Instrumentos Utilizados para a Coleta de Dados}

. Depois de elaborada a mesma foi amplamente divulgada por meio de ferramentas de mídias sociais,como Facebook, Instragram e Whatsapp. Foi informado ao respondente que o anonimato era garantido, a partir disto coube ao mesmo decidir se respondedia ou não a pesquisa em questão, invalidando assim a possibilidade de afirmar que todos que receberam a mesma responderam. Como forma de reforçar este anonimato em todas as publicações e na introdução da pesquisa era resaltado e afirmado o anonimato do respondente e com isso se pedia que fosse inteiramente sincero em relação as suas respostas para que se obtivesse a maior veracidade os resultados obtidos por esta pesquisa.

\subsection{Limitações do Estudo}

Por se tratar de um estudo com um tema que é pouco pesquisa o mesmo apresenta limitações, como por exemplo, no fato de ter pouca base para se utilizar como bibliografia, como por exemplo artigos e pesquisas com este tema. Além do fato de estar medindo um ponto intangivel, que seria a cultura dos colaboradores. Este fato pode dificultar a forma que o respondente percebe como a mesma o impacta e como ele considera que impacta. 
4 Análise e Intepratação dos Resultados

O capítulo de análise e interpração dos resultados apresenta os dados levantados a partir da pesquisa quantitativa realizada, assim como a relação com o referencial teorico apresentado anteriormente. As hipóteses levantadas como fundamento para para que a pesquisa fosse estruturada, também serão validadas ou não, com os resultados obtidos.

O primeiro bloco de questões tem como função a delimitação que a pesquisa propõem, são perguntas que auxiliam em identificar se o respondente tem realmente o perfil buscado pela pesquisa, caso a resposta seja negativa a pesquisa se encerra mas se a resposta por positiva o mesmo é encaminhado para as seguintes questões do segundo bloco.

No segundo bloco são feitas perguntas que estão relacionadas com as hipoteses propostas por este estudo, a fim de validadas ou não e também em relação ao referencial teorico apresentado neste estudo.

\subsection{Descrição e Análises do Resultado}

Está seção está dividada em dois blocos, onde o primeiro bloco da pesquisa contava com uma pergunta delimitadora para que se tivesse o perfil de respondentes desta pesquisa, caso a resposta fosse positiva o mesmo era direcionado as questões que montariam o perfil daquele respondente, que seriam a qual empresa o mesmo trabalhava ou já tinha trabalhado, que tipo de organização era, a quanto tempo trabalhava ou tinha trabalhado, seu gênero, escolaridade, nivel dentro da organização, qual área o mesmo trabalhava ou trabalha, cargo que o mesmo exercia e a sua idade. Deste total apenas 108 dos respondentes trabalhavam ou já trabalharam em alguma multinacional ou empresa que sofreu fusão e aquisição, os demais a pesquisa foi encerrada após responder esta pergunta. Já no segundo bloco foram feitas perguntas que queriam avaliar a percecpção dos colaboradores destas empresas em relação 
ao multiculturalismo dentro da organização e os impactos que o mesmo pode gerar. A figura abaixo mostra o percentual de respondentes dentro e fora do perfil da pesquisa que participaram da mesma.

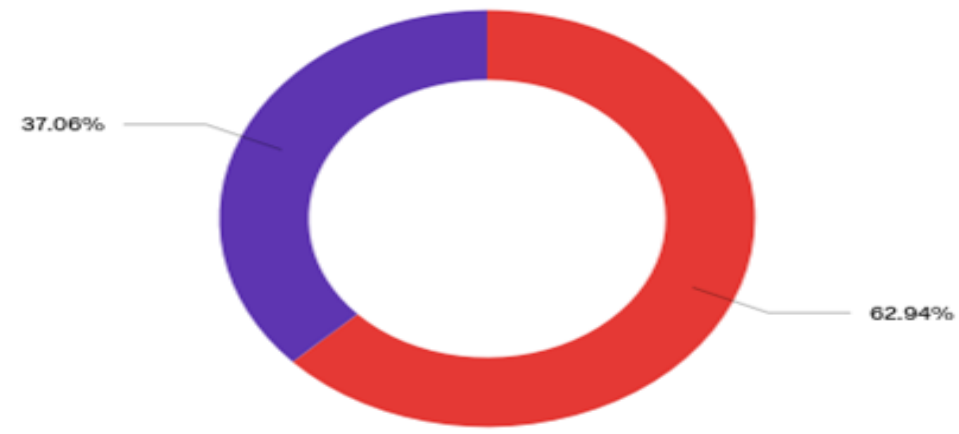

Fonte: Autora

Figura 3 - Porcentagem de respondentes que já trabalharam ou trabalham em empresas Multinacionais ou que sofreram processo de Fusão e Aquisição.

Destes 108 que se enquadravam dentro do perfil pedido pela pesquisa, foi possivel observar que $62,04 \%$ dos respondentes são colaboradores de empresa multinacionais e $13,98 \%$ são colaboradores de empresas que sofreram processos de fusão e $15,74 \%$ de processos de aquisição.

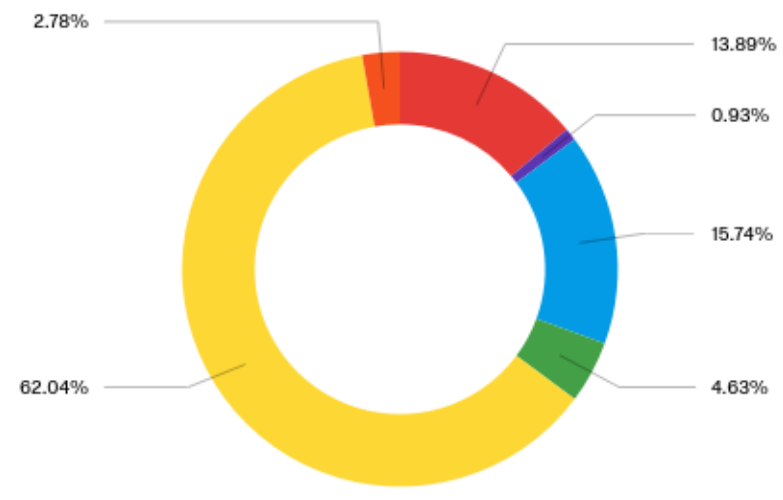


$\mathrm{Na}$ próxima questão foi possivel identificar todas as empresas que os respondentes com o perfil adquado eram ou são colaboradores, por conta da intensa divulgação foi possivel captar respondentes de inúmeras empresas diferentes dentro do perfil pedido pela pesquisa. Como pode ser visto no anexo 2, 55 empresas diferentes tiveram colaboradores que participaram da pesquisa. Sendo as empresas com mais colaboradores respondentes foram: Servier (15), AMBEV (8), Bioagri (7), Santander (5) e IBM (5).

Com a grande diversificação de empresas é possível ter diferentes percepções dos colaboradores em relação a integração de culturas diferentes que existem dentro da mesma e como eles avaliam as caracteristicas deste fato.

A partir do cruzamento de duas perguntas é possivel identificar quais os niveis estrategicos dos respondentes dentro das organizações que os mesmos trabalham e em qual área o mesmo trabalha. A partir destes dados foi identificado que as áreas que mais aparecem na pesquisa são as áreas comerciais, de marketing, recursos humanos e opções que não estavam listadas como opções na pesquisa, sendo assim foi selecionada a opção "outros", tendo como resposta áreas como de atendimento e engenharia das empresas em questão. Como está sendo mostrado na tabela abaixo.



Figura 5 - Tabulação em relação as áreas dos colaboradores e níveis dentro da organição

Fonte: Autora 
Na próxima tabela é possível identificar a relação feita entre o gênero dos respondentes e idade dos respondentes. A partir destes resultados foi possivel identificar que dentro as faixas etárias estabelecidas pela pesquisa se obtiveram um maior número de respondentes mulheres, na maioria das faixas etárias evidenciadas na pesquisa, apenas a faixa de 31-40 tem um número de respondentes masculino maior que o feminino. Como é possivel visualizar na tabela abaixo:

\begin{tabular}{|c|c|c|c|c|c|c|c|c|}
\hline & & \multicolumn{6}{|c|}{ 9) Quantos anos você tem? } & \multirow[b]{2}{*}{ Total } \\
\hline & & até 20 anos & $21-25$ & $26-30$ & $31-40$ & $41-50$ & Acima de 50 anos & \\
\hline \multirow{4}{*}{ 10) Qual seu gênero? } & Feminino & 0 & 38 & 17 & 4 & 4 & 1 & 64 \\
\hline & Masculino & 1 & 22 & 11 & 6 & 1 & 2 & 43 \\
\hline & Outros & 0 & 0 & 0 & 0 & 0 & 0 & 0 \\
\hline & Total & 1 & 60 & 28 & 10 & 5 & 3 & 107 \\
\hline
\end{tabular}

Fonte: Autora

Figura 6 - Faixa etária em relação ao gênero

Já nas questões seguintes foi obtido um resultado a partir do grau de escolaridade e do cargo exercido na organização pelo respondente. A partir disto foi possivel identificar que grande parte dos respondentes são estagiários, analistas e assistentes de área dentro da organização. Como a pesquisa tem um alcance maior dentro das faculdades, visto que esta pesquisa está ligada a um projeto de formação de graduação, o resultado obtido está dentro do esperado.

Como é possivel ver na tabela abaixo:

7) Qual é seu cargo na organização?

\begin{tabular}{|c|c|c|c|c|c|c|c|c|}
\hline & \multicolumn{7}{|c|}{ 6) Qual sua escolaridade? } & \multirow[b]{2}{*}{ Total } \\
\hline & Fundamental & Médio & Superior & Pós-graduação & Mestrado & Doutorado & Outros & \\
\hline Estagiário & 0 & 1 & 30 & 1 & 0 & 0 & 1 & зз \\
\hline Assistente de área (nível escolar médio) & 0 & 5 & 12 & 0 & 0 & 0 & 0 & 17 \\
\hline Analista de área (nivel escolar superior) & 0 & 0 & 30 & 4 & 2 & 0 & 0 & 36 \\
\hline Gerente de área & 0 & 0 & 4 & 2 & 2 & 1 & 0 & 9 \\
\hline Diretor & 0 & 0 & 0 & 0 & 2 & 0 & 0 & 2 \\
\hline Outros & 0 & 1 & 5 & 2 & 1 & 1 & 0 & 10 \\
\hline Total & 0 & 7 & 81 & 9 & 7 & 2 & 1 & 107 \\
\hline
\end{tabular}

Fonte: Autora 
É possivel identificar também que nas duas tabelas anteiromente apresentadas o número total é diferente do número total de respondentes dentro do perfil da pesquisa, o que possibilita afirmar que pelo menos um dos respondentes deixou de responder algumas das perguntas em questão modificando assim o número final destas tabelas.

Após estas questões que mapeam o perfil do respondente e como está alocado dentro da organização o mesmo foi direcionado a perguntas que validariam ou não as hipoteses levantadas por esta pesquisa e que se relacionam ao referencial teorico desta pesquisa.

Já no segundo bloco da pesquisa é composta por questões que estão relacionadas as hipoteses criadas e ao refenrecial teorico previamente apresentado nesta pesquisa. A primeira pergunta pedia para que o respondente apontasse os três principais pontos que o mesmo identificava diferente a sua cultura em relação a cultura da empresa que o mesmo trabalha ou já tinha trabalhado. Segundo Chiavenato (2005, p. 165) a cultura é difícil de mudar, principalmente em um nível mais profundo, com valores e pressuposições básicas. O multiculturalismo significa a existência de muitos e diferentes elementos e fatores culturais trazidos às organizações por pessoas provavelmente de diferentes culturas e que coexistam e florescem dentro das organizações.

Baseando-se na teoria acima é possivel identificar que cultura é algo muito dificil de se mudar, seja a pessoal ou a que a empresa prega e com isso os respondentes apontaram quais os três principais pontos que os mesmos identificaram diferentes em relação a sua cultura, é de suma importância que a organização saiba lidar com esses choques culturais para que o colaborar não se sinta desconfortavel no ambiente de trabalho. Abaixo é possivel identificar que os pontos mais citados pelos respondentes como fator de maior choque em relação a sua cultura foram: Objetividade, Comunicação e Pontualidade Rigida. 


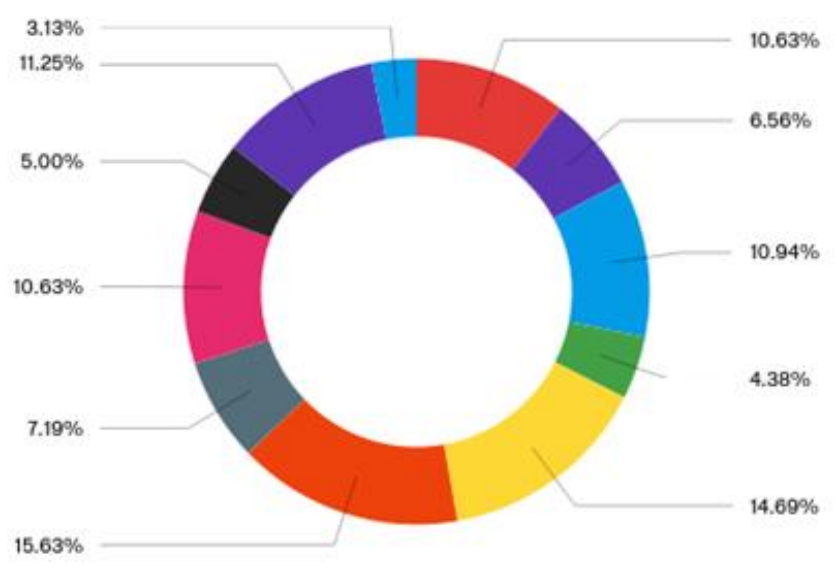

\section{Figura 8 - Principais pontos da diferença cultura}

Fonte: Autora

Com a próxima questão é possivel não validar umas das hipóteses propostas por está pesquisa, a mesma diz: Empresas multinacionais tentam descareterizar os colaboradores com culturas diferentes para os mesmos seguirem a cultura que a mesma prega; A partir das respostas coletadas foi possivel identificar que os respondentes avaliam que a empresa que o mesmo trabalha ou já trabalhou é bastante diversificada, obtendo um percentual de $38,46 \%$ dos respondentes, e com isso a a hipotese proposta não se faz verdadeira,visto que os mesmos identificam que a diversidade está bastante presente dentro da mesma e com isso não ocorre a descaracterização da cultura dos seus colaboradores. 


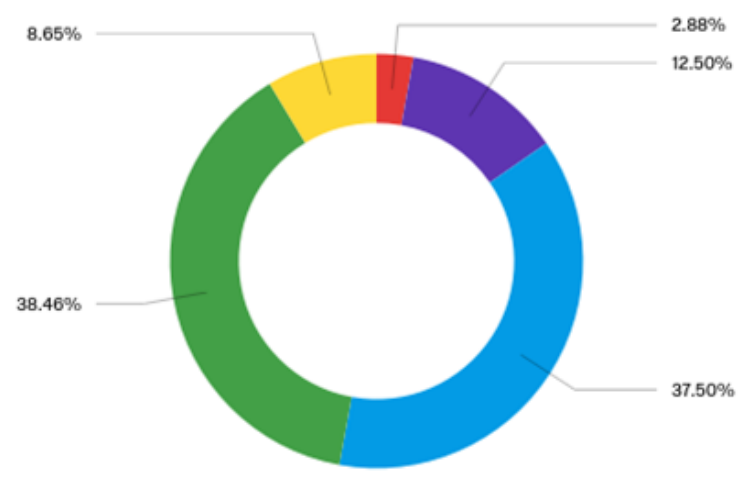

Nenhuma diversidade

Pouca diversidade

Razoavelmente diversificada

Bastante diversificada

Totalmente diversificada

Figura 9 - Diversidade presente nas organizações

Fonte: Autora

Com a próxima questão tem-se a intenção de medir se os respondentes avaliam se a organização lida bem ou não com a diversidade presente dentro da mesma, com essa questão é possivel comprovar a teoria citada no referencial em relação a organizações multiculturais. Segundo Paiva (2012), nos tempos atuais, os movimentos culturais, raciais, feministas e outros têm trazido à tona a multiplicidade de identidades dentro de uma nação. As organizações lidam com culturas diversas, dentro ou fora do espaço nacional, o que demanda uma análise em uma perspectiva que vai além do caráter multinacional das organizações, percebendo-as como organizações multiculturais.

E a partir desta questão é possivel não validar outra hipótese proposta por esta pesquisa, a mesma diz: Colaboradores com culturas diferentes não conseguem quebrar a barreira em relação as suas caracteristicas diferentes e com isso não ocorre aproximação e integração; Pois com o percentual de muito bem com $35,58 \%$ e o percentual de bem $38,46 \%$, chegasse a um total de $74,04 \%$ de organizações que lidam muito bem ou bem com a questão da diversidade e com isso a tendência de quebrar a barreira gerada pela questão das culturas diferentes se torna mais fácil, visto que a empresa auxilirá nesse processo e assim facilitará que o mesmo ocorra. 


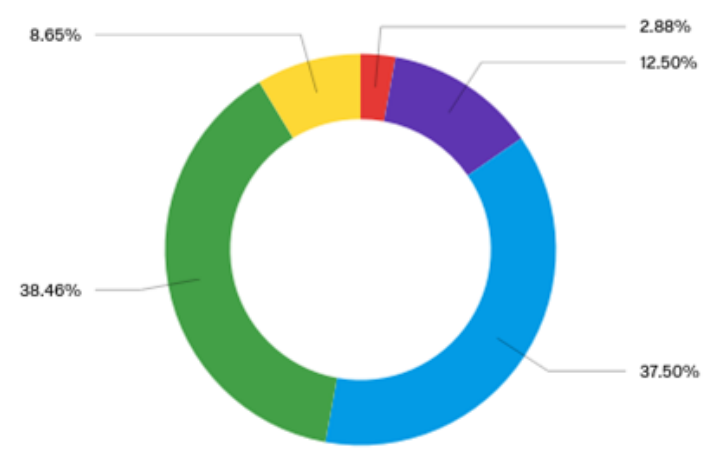

Figura 10 - Percepção de como a organização lida coma diversidade

Fonte: Autora

Conforme já citado no referencial teorico equipes multiculturais trazem inúmeros beneficios para a organização, segundo Parke (1995) trabalhar em e com times "multiculturais" e operar em mercados culturalmente diversos passou a ser parte integrante do cotidiano organizacional, um diferencial competitivo para jovens gerentes e uma exigência básica para qualquer líder organnizacional.

A diversidade além de trazer um diferencial competitivo para as organizações também possibilitam beneficios internos para a mesma, nesta questão os respondentes apontaram os cinco principais beneficios para a organização e os mais citados foram: Criatividade (13,03\%), Riqueza intelectual e cultural (11,81\%), Integração entre áreas (9,37\%), Ambiente harmônico no trabalho (8,55\%) e Motivação (7,74\%).

Com os pontos levantados é possivel afirmar que a diversidade traz beneficios não só para a organização mais também para o próprio colaborador pois com essas boas práticas o mesmo se sente motivado em ir trabalhar e dispõe de uma bom ambiente para trabalhar e assim a empresa ganha pois conseguirá atingir bons resultados no futuro e o colaborador também já que se sente bem naquele ambiente e gera um bem-estar para o mesmo no trabalho. 


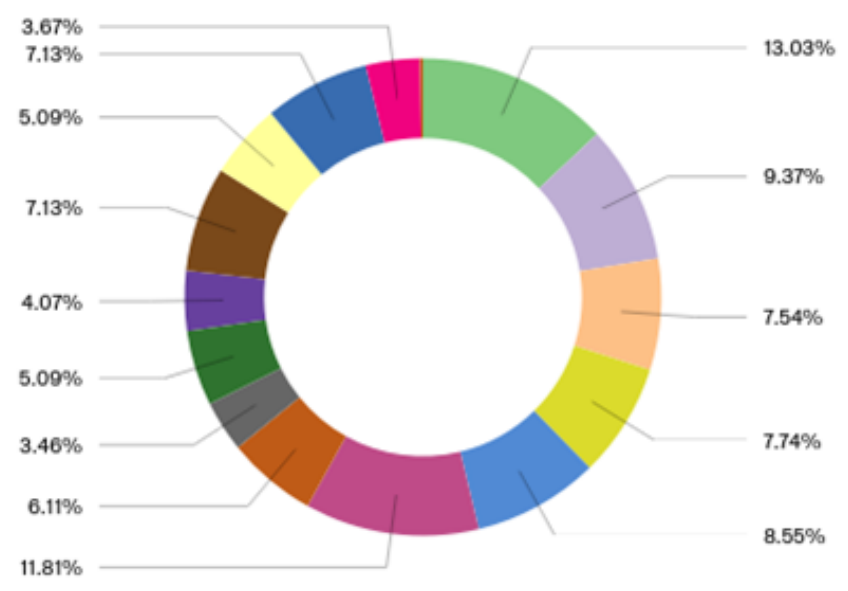

Criatividade

Integraçāo entre as áreas

Produtividade

Motivaçăo

Ambiente Harmônico de trabalho

Riqueza intelectual e cultural

Igualdade de oportunidades

Boa reputação no quesito de empregabilidade

Identificaçāo de clientes com perfis variados

Liberdade de decisāo

Figura 11 - Beneficios da diversidade nas organizações

Autora: Fonte

Na pesquisa se fez necessário diferenciar clima organizacional de cultura, pois é sabiado que existe uma certa confusão em relação as duas tematicas. No refencial foi citado as duas teorias e no questionario se fez necessário avaliar como os respondentes avaliavam o clima da organização em que trabalham. Com isso foi possivél identificar que as organizações apresentam um clima agradável e nenhum dos respondentes avaliou que o clima da sua organização fosse muito ruim. Como podemos ver abaixo, o clima organizacional agradável nas organizações obteve um percentual de $62,50 \%$.

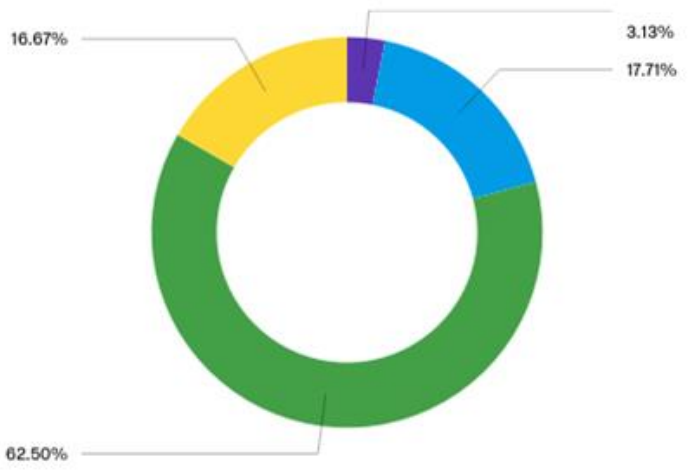


A partir das próximas perguntas ficou claro que o departamento de Recursos Humanos das organizações desempenha um papel fundamental na implementação das teorias de multiculturalismo nas organizações, visto que o mesmo desempenha o papel de passar para os colaboradores todas as mudanças na organização e, também, apresentar os novos colaboradores da mesma. Foi pedido aos respondentes identificarem as três principais ações do departamento de recursos humanos nas organizações para aproximar colaboradores com culturas diferentes, os mais citados foram: Evento de final de ano com os colaboradores (15,11\%), Comunicação interna para aproximar os colaboradores $(13,50 \%)$ e Comemoração de metas alcançadas (10,93\%).
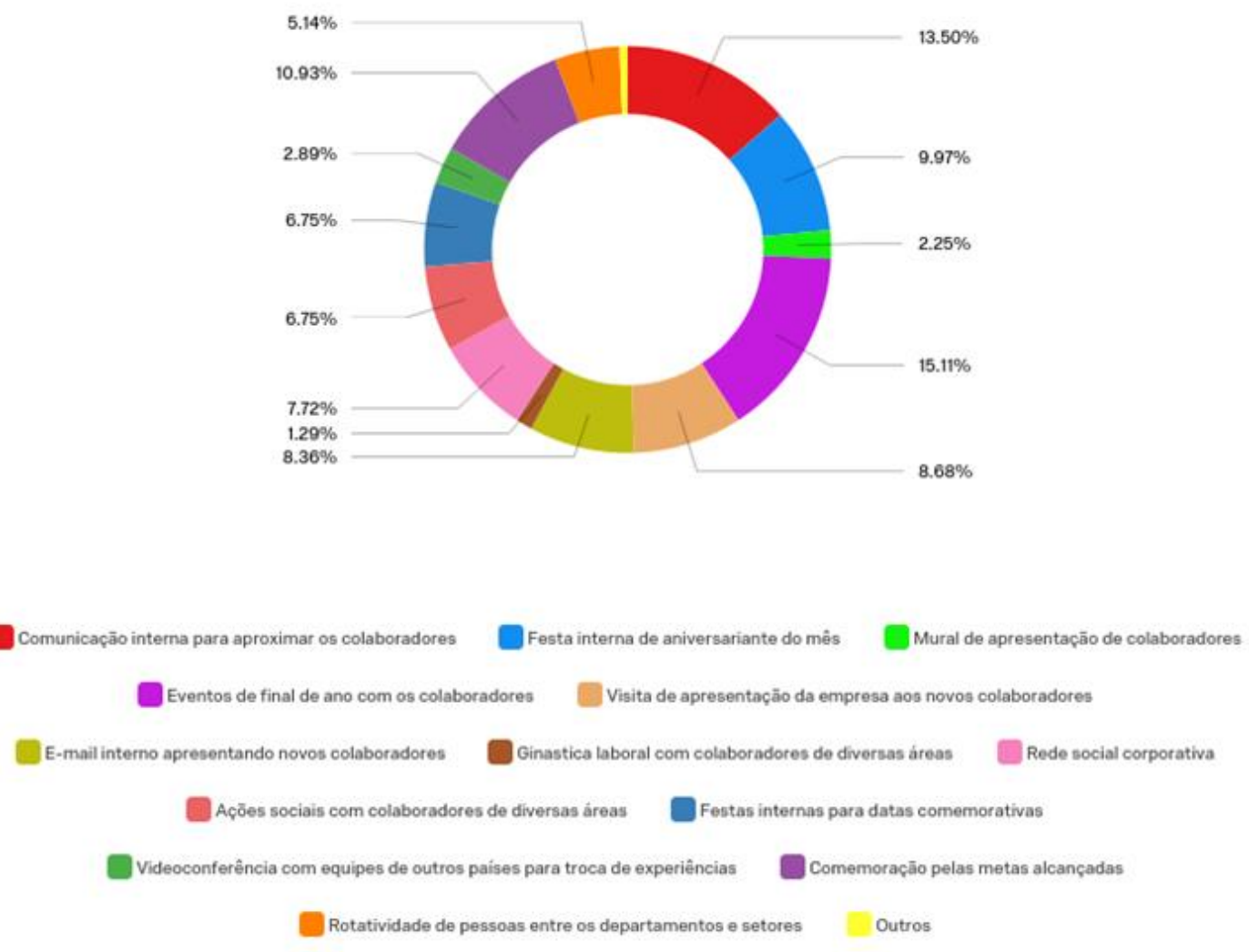

Figura 13 - Ações do departamento de Recursos Humanos

Fonte: Autora 
Já na próxima questão os respondentes avaliaram o quão aberto o departamento de Recursos Humanos é aberto a ouvir suas opiniões e como se sentem em relação de tomar essa iniciativa. Com está questão foi possível invalidar outra hipotese, já que os respondentes em questão se sentem totalmente confortaveis em opinar junto ao departamento de recursos humanos da sua organização. Mostrando assim que as empresas entendem que é necessário ouvir a opinião do seu colaborador e demonstrar a possibilidade que o mesmo tenha a atitude e segurança em falar com o departamento de Recursos Humanos quando achar necessário e não apenas em situações formais dentro da organização.

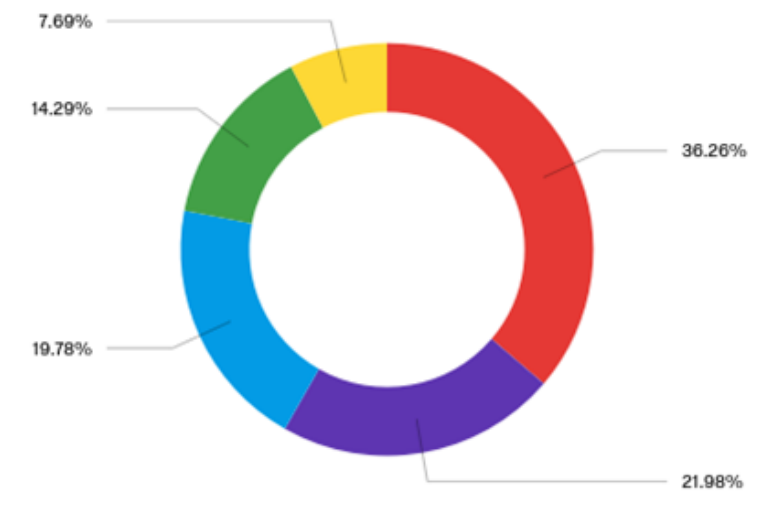

Totalmente confortável para opinar, o RH da minha organizaçăo é bem acessivel

Sim, porém apenas de maneira formal através de pesquisas gerenciadas pelo RH

Eventualmente e em casos especificos que estejam normatizados.

Não me sinto muito confortável para opinar junto ao RH

O RH nāo é acessivel às opiniōes dos empregados em geral.

Figura 14 - Nivel de estímulo do departamento de Recursos Humanos para os colaboradores opinarem

Fonte: Autora

Com base nas referencias já apresentadas neste estudo é possivel reafirmar o papel determinante do departamento de Recursos Humanos e como o resultado obtido por está pesquisa se torna benefico, visto que quando se dispõe de uma $\mathrm{RH}$ aberto a opinões o colaborar se sente mais seguro em expor suas causas sem o medo de possa acontecer algo de ruim com o mesmo e com isso não gera impacto no clima da organização e não dificulta que os colaboradores absorvam de melhor forma a cultura da organização além do fato de não impactar negativamente na motivação do colaborar visto que o mesmo 
ao sentir um impacto ruim sente que é possivel expor isso ao departamento de Recursos Humanos da organzação.

Medir como as organzações lidam com as mudanças organizacionais é de suma importancia no mundo moderno, pois a mesma representa a principal característica dos tempos modernos.

E assim se fez necessário medir como os colaboradores avaliam que as organizações lidam com essas mudanças, visto que quando não se lida bem com as mesmas geram inúmeros impactos negativos, já que as mudanças estão presentes em toda a organização e com isso impacta desde o nível mais alto da mesma até o mais operacional. A partir dos dados coletados foi possivel identificar que as empresas em questão lidam bem com os processos de

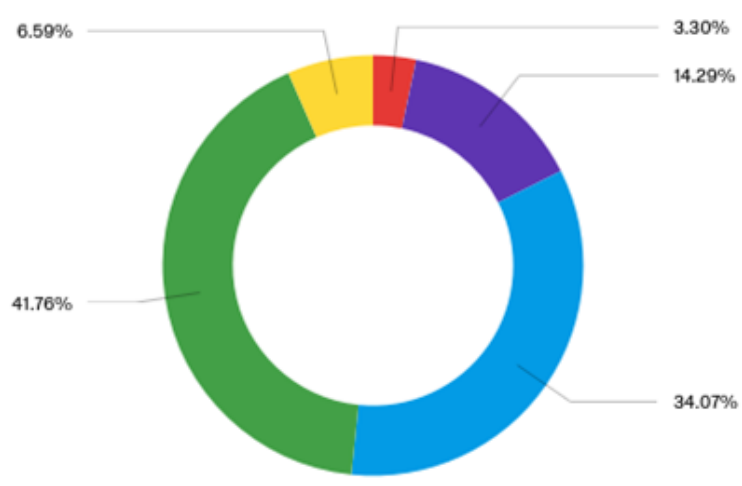

Medidas que nāo impactam em nada

Medidas que nāo impactam muito

mudanças que possam ocorrer nas organizações, diminuindo assim a possibilidade de impactos negativos para a mesma e seus colaboradores.

Figura 15 - Percepção em relação as medidas tomadas quando ocorrem mudanças nas organizações

Fonte: Autora

Em relação as respondentes desta pesquisa $41,76 \%$ dos mesmos avaliam que suas organizações tomam boas medidas quando ocorrem mudanças na organização, sendo assim fica claro que as empresas estão se concientizando de que lidar com as mudanças é algo que estará cada vez mais presente nas 
organizações modernas, visto que a maior integração não só das organizações mas de todo o mercado provocam mudanças mais frequentes.

A partir da mudança organizacional é se suma importância que os colaboradores tenham conhecimento da mesma e com isso o departamento de Recursos Humanos se faz presente novamente como principal responsável em disseminar dentro da organização as mesmas, e com isso existem formas mais comuns de ser feito. Sendo assim foi pedido para os respondentes destacarem os três principais meios que sua organização utiliza para que as mudanças sejam comunicadas aos colaboradores, das opções apresentadas aos respondentes as que mais foram citadas são: Comunicados feitos via intranet (emails, comunicados e avisos) (29,96\%), Reuniões periodicas (16,25\%) e Quadro de avisos $(10,47 \%)$.

A partir destas respostas é possivel identificar que o departamento de Recursos Humanos utiliza de tudo que tem a sua disposição para deixar claro para seus colaboradores essas mudanças, utilizando de formas diferentes para que ocorra o reforço desta mudança, visto que com as ações que mais foram citadas é possivel dizer que a organização utiliza de meios que não são completamente diretos como no caso dos quadros de aviso que ficam espalhados pela organização e que pode não ser efetivo de fato, já com os comunicados via intranet é possivel ter uma certeza maior de que aquele comunicado de fato chegou ao seu colaborador e para reforçar de fato que a

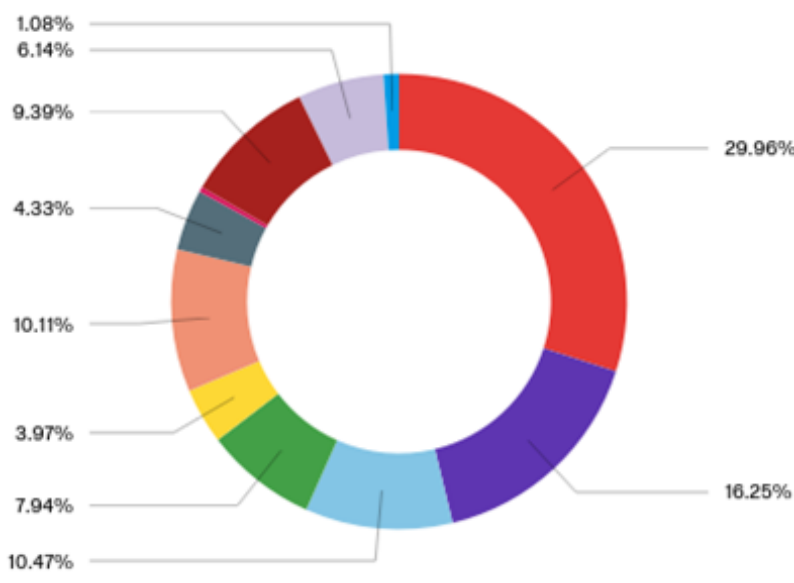

Comunicados feitos via intranet (e-mails,comunicados e avisos) 
mudança chegará a quem se espera são feitas reuinões periodicas onde são expostas as mudanças que ocorram na organização.

As duas questões a seguir medem a percepção dos respondentes em relação a quanto os mesmos consideram que são impactados pela cultura da organização e como impactam a mesma. Como já dito anteriormente cultura é algo dificil de mudar mas quando se convive com diversas culturas se torna inevitavel não absorver alguma caracteristica para si. Sendo assim é possivel validar uma das hipóteses propostas por esta pesquisa, a mesma diz: Como a teoria de multiculturalismo é percebida na prática;

Segundo Chiavenato (2005, p.165) o multiculturalismo significa a existência de muitos e diferentes elementos e fatores culturais trazidos às organizações por pessoas provavelmente de diferentes culturas e que coexistam e florescem dentro das organizações. Pois quando os colaboradores se sentem influênciados por uma cultura diferente ou influênciam a cultura da organização deixa claro que as culturas em questão coexistem e florecem de forma positiva, já que quando se agrega algo da cultura diferente imagina-se que seja algo que trará um maior valor positivo para quem está absorvendo a mesma. Na primeira questão se obteve um percentual de $41,76 \%$ de que a cultura diferente influênciou razoavelmente a cultura do respondente. Seguido de 26,37\% de uma consideravel influência na sua cultura, deixando claro que os respondentem avaliaram que a convivência das culturas diferentes impactam sempre de alguma forma nas pessoas que estão naquele ambiente.

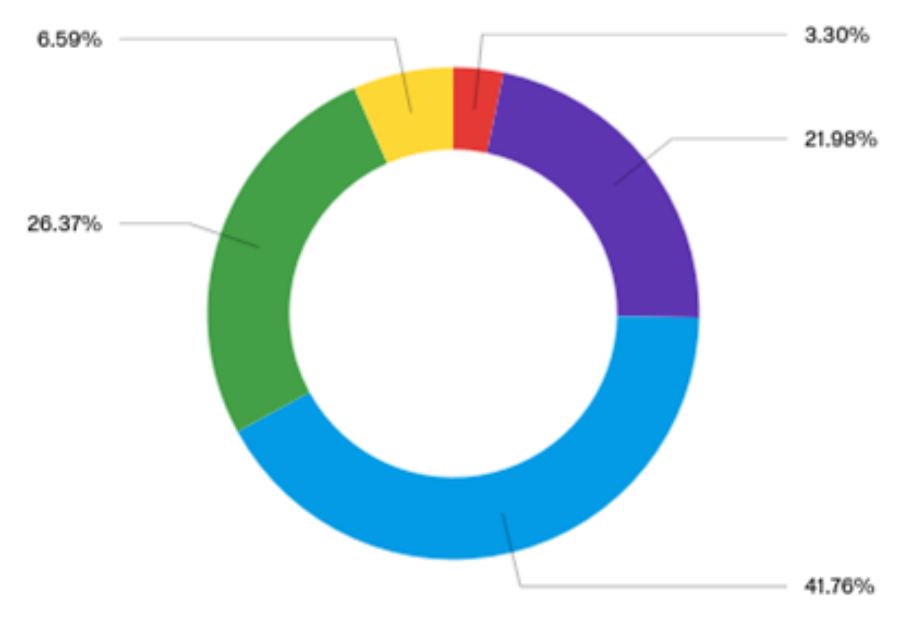


Já na pergunta seguinte o respondente avaliou como o mesmo impacta na cultura da organização, neste caso os respondentes avaliaram que impactam razoavelmente na organização, obtivo um percentual de $37,36 \%$. Mostrando a relação que existe entre as duas questão, já que assim como o colaborador absover alguma caracteristica para si a organização se comporta da mesma forma.

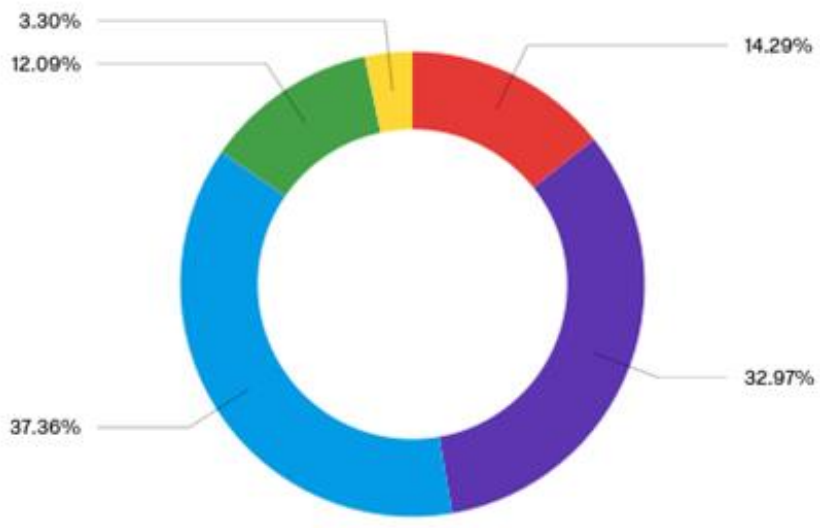

Figura 18 - Impactos na cultura organizacional

Fonte: Autora

As perguntas finais desta pesquisa buscavam medir quais os três principais pontos que os respondentes avaliavam como positivos em relação à cultura da organização e a sua cultura. Com relação às questões anteriores e as teorias citadas é possivel identificar em relação a cultura de origem da organização as mais citadas estão mais relacionadas ao lado mais profissional que está presente na cultura diferente, visto que os mais citados foram: Tecnologia (15,69\%), Ênfase no planejamento ao longo prazo (13,50\%) e Criatividade $(13,14 \%)$, fatores que não demonstram o perfil da pessoa que tem aquela cultura e sim o perfil organizacional das empresas. 

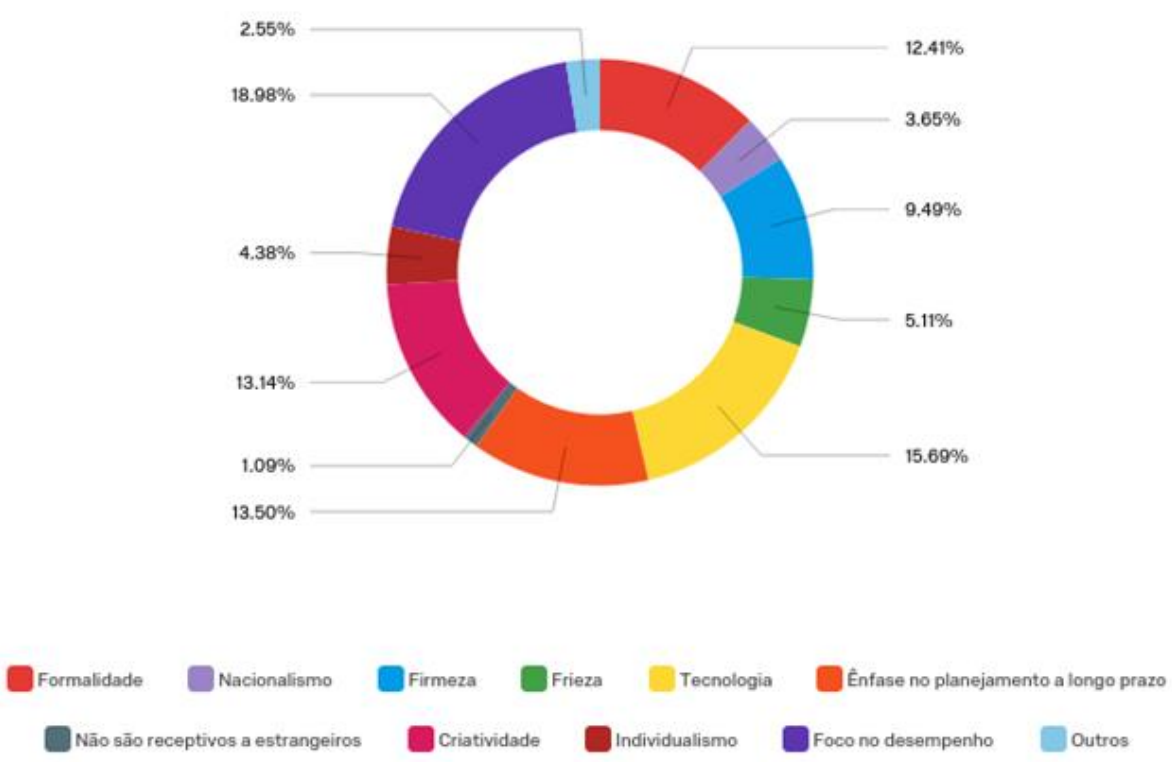

Figura 19 - Pontos positivos em relação a cultura do país de origem da organização

Fonte: Autora

Já em relação a cultura do Brasil, já que foi pedido para avaliar as principais caracteristicas positivas da nossa cultura foi possivel identificar pontos que estavam mais interligados às questões pessoais e não tanto organizacionais. Os três principais pontos citados foram: Flexibilidade $(22,34 \%)$, Ênfase em relações pessoais $(20,88 \%)$ e Hospitalidade $(19,05 \%)$. Deixando claro que o povo brasileiro é visto mais pelas suas caracterisitcas pessoais e em relação a sua grande fama conhecida de ser um excelente país em receber estrangueiros e a forma que os mesmos são tratados no nosso país, fazendo com que as caracteristicas pessoais do nosso povo chamem mais atenção que as caracteristicas profissionais.
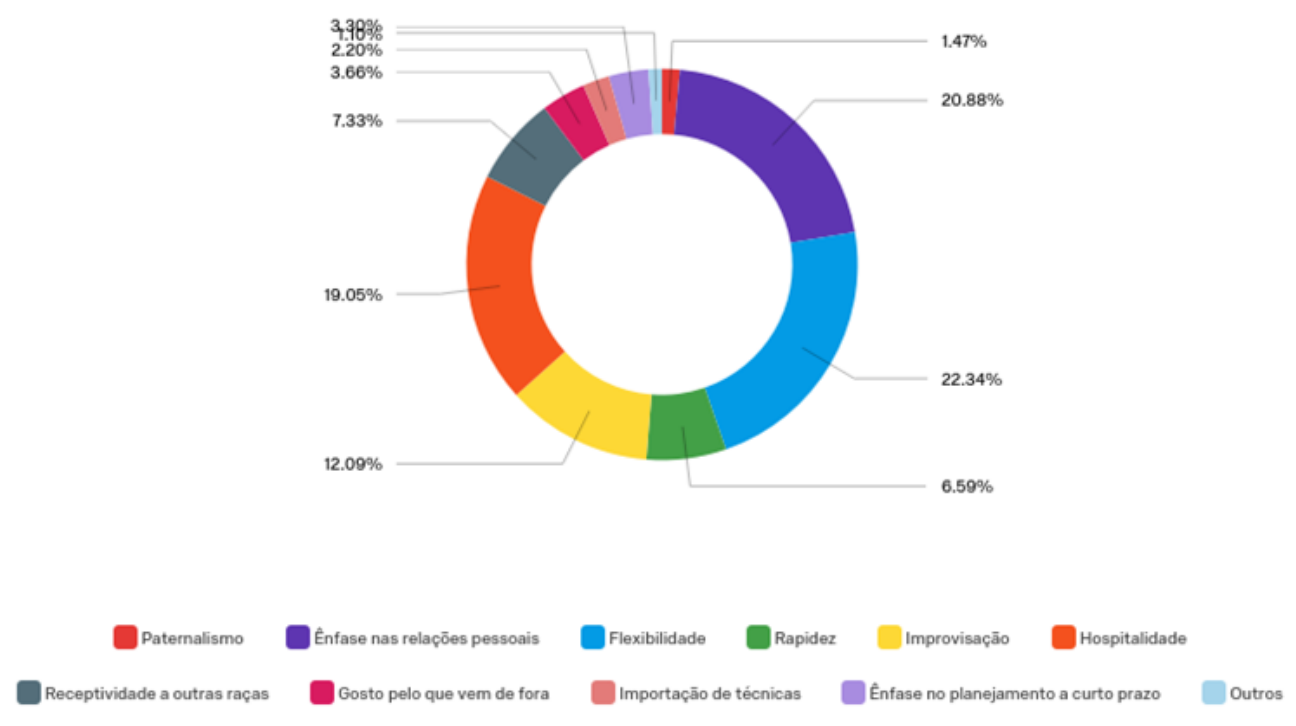

Figura 20 - Pontos positivos em relação a nossa cultura 


\section{Conclusão}

Este capítulo apresenta as observações finais do trabalho em questão, levando em consideração a opinião da autora deste estudo, incluindo as ponderações e reflexões da mesma em relação aos resultados obtidos da pesquisa realizada. Além disso, são demonstradas as contruibuições ao estudo, evidenciadas as limitações do mesmo e elaboradas sugestões para os futuros estudos quem envolvam o tema em foco.

No atual milênio, a pluralidade cultural é um aspecto importante que deve ser levado em conta no cotidiano das relações dentro das organizações e destas com a sociedade multicultural que as circunda. O multiculturalismo é mais do que culturas ligadas a diferentes povos e nações, ele está presente dentro das organizações, o que exige, por parte do pessoal que nelas atuam, sensibilidade e abertura para pontos de vista e identidades diferentes (CANEN, 2005). O que este presente estudo procurou descobrir foi como o multiculturalimos impacta na cultura organizacional e como os seus colaboradores avaliam que são impactados por conviver com culturas diferentes e com os mesmos percebem que impactam a cultura organizacional.

Foi realizada uma pesquisa quantitativa com 108 participantes que trabalham ou já trabalharam em alguma multinacional ou empresa que sofreu fusão ou aquisição em empresas localidadas no Rio de Janeiro, através da ferramenta Qualtrics. A pesquisa foi realizada de forma anônima, esta informação foi bastante enfatizada para os participantes para que os mesmos se sentissem inteiramente confortaveis para responder de forma mais verdadeira pra que o estudo obtivesse os resultados mais veridicos em relação a opinião dos respondentes.

A partir dos resultados obtidos após o encerramento da pesquisa, pode-se observar que os colaboradores sentem que influênciam a cultura organizacional e se sentem impactados pela mesma, a partir da primeira afirmação os participantes deixaram claro que se sentem que impactam razoavelmente na cultura da organização, com $37,36 \%$ dos respondentes. Já na segunda afirmação os participantes se sentem influênciados razoavelmente em relação a sua cultura pessoal, com $41,76 \%$ dos respondentes. O professor de 
comunicação intercultural americano William Hart (2001 apud GUITEL, 2006) classifica os trabalhos sobre as culturas em três categorias ou níveis: uma fase monocultural, uma fase transcultural, e uma fase mais avançada, que é o nível intercultural. A fase monocultural se refere à observação de uma cultura de forma exclusiva; a fase transcultural se refere à comparação de diferentes características culturais de uma cultura para outra, tendo como referência um conjunto de variáveis compartilhadas; e a fase intercultural trata da interação de culturas, a partir do processo interativo em si até suas consequências. $O$ processo é dinâmico.

Segundo Lewin (apud Chiavenato 2010) a mudança é um aspecto essencial da criatividade e inovação nas organizações de hoje. A mudança está em toda parte: nas organizações, nas pessoas, nos clientes, nos produtos e serviços, na tecnologia, no tempo e no clima. A mudança representa a principal característica dos tempos modernos. A mudança envolve transformação, interrupção, pertubação, ruptura, dependendo da sua intensidade. Os resultados da pesquisa demonstra que $41,76 \%$ das empresas tomam boas medidas em relação as mudanças organizacionais que possam ocorrer na mesma, se baseando nisso fez importante resaltar que o departamento de Recursos Humanos tem um papel importantissimo nesse momento, nesta pesquisa obtevesse um resultado em relação a como o $\mathrm{RH}$ deixa o seu colaborador a vontade para opinar em relação as mudanças da organização, foi obtido como resultado que $36,26 \%$ das organizações dos participantes dão ampla abertura para que o colaborador opine junto ao $\mathrm{RH}$.

Foi avaliado também as formas que o $\mathrm{RH}$ comunica aos colabores às mudanças da organização, foram apontados os três principais meios, sendo eles: Comunicados feitos via intranet (comunicados, e-mails e avisos) (29,96\%), Reuniões periódicas (16,25\%) e Quadros de avisos (10,47\%). Outro fato que foi levado em consideração também foi quais os ações que o departamento em questão faz para que os colaboradores com culturas diferentes se aproximassem, foram obtidos como resultado que as três principais ações são: Evento de final de ano com os colaboradores (15,11\%), Comunicação interna para aproximar colaboradores (13.50\%) e Comemoração por metas alcançadas $(10,93 \%)$.

O levantamento desses dados foi importante para evidenciar que a integração das culturas acarretam mais pontos positivos do que negativos, tanto para o colaborador como para a organização, a maior integração faz com que lacunas que podem existir em uma cultura sejam complementadas por 
caracteristicas que podem existir na outra, fazendo assim com que a integração facilite na integração independente de qual parte do mundo a pessoa pode estar, visto que com a globalização o mundo se torna uma teia de pontos interligados e se faz de suma importância que se saiba lidar com as diferenças, sejam elas intelectuais ou pessoais.

A primeira sugestão a ser feita é que o departamente de Recursos Humanos nas organizações aumente a frequência de ações para a integração dos funcionarios, visto que com essa maior frequência a barreira que pode existir em relação ao "choque cultural" que possa ocorrer de ambas as partes sejam quebradas a cada encontro, existem inúmeras formas que não geram custos altos para a organização, que podem ser implementadas, como videoconferências para troca de experiências, ginastica laboral eventualmente na organização que mescle todas as áreas da organização para que ocorra uma maior integração da mesma. Além disso estar sempre aberto para ouvir o seu colaborador para que o mesmo tenha confiança na organização que pertence para que em dado momento que o mesmo não se sinta totalmente confortavel com ambiente em que está inserido o mesmo tenha um local que se sinta seguro para expor seus preocupações e questões. 


\section{Referências Bibliográficas}

BARBOSA, Livia - Cultura e diferença nas organizações: reflexões sobre nós e os outros - $1^{\text {a }}$.ed - São Paulo: Atlas, 2009 - 2ª .ed reimpressão

BOWDITCH, James L. Elementos de comportamento organizacional. 2. Ed. São Paulo: Pioneira, 1997.

CANEN, A.G. CANEN, A. Organizações multiculturais: a logística na corporação globalizada. Rio de Janeiro: Ciência Moderna, 2005.

CHAMPION, Dean. Sociologia das organizações. São Paulo: Brasiliense, 1988.

CHIAVENATO, Idalberto - Gestão de Pessoas: o novo papel dos recursos humanos nas organizações - 3 ${ }^{\text {a }}$ ed. - Rio de Janeiro: Elsevier, $2010-6^{\underline{a}}$ reimpressão.

CHIAVENATO, Idalberto. Administração nos novos tempos. $2^{\text {a }}$.ed. $\mathrm{S} / \mathrm{L}$ : campos, 2005.

CODA, R. - Pesquisa de clima organizacional: Uma contribuição metodológica. Tese de Livre-Docência nãopublicada, Universidade de São Paulo, São Paulo,1998.

FELLOWS, Zauili Amanda - Diversidade Cultural. [recurso eletrônico] Competências para gerencia-lá. 2004

GIL, A. C. Como elaborar projetos de pesquisa. São Paulo: Atlas, 2002. ISBN: 8522431698.

GIL, A. C. Como elaborar projetos de pesquisa. São Paulo: Atlas, 2010. ISBN: 9788522458233.

GUITEL, V.D. Intercultural or crosscultural management? The confirmation of a research field and the issue concerning the definition and development of an intercultural competence for expatriates and international managers. Revista E\&G Economia e Gestão. Belo Horizonte, v. 6, n. 12, p. 64-68, jun. 2006. Disponível em $<$ http://portal.pucminas.br/documentos/editora economia gestao 12.pdf>. Acesso em 02 de junho de 2018. HOFSTEDE, G. Culturas e organizações: compreender a nossa programação mental. 1.ed. - 2. reimpr. Lisboa: Edições Sílabo, 1991.

LIMA,Suzana Maria Valle - Mudança Organizacional: teoria e gestão - Rio de Janeiro: Editora FGV, 2003.

PAIVA, Vilhena de Perez Marcia - Cultura Organizacional em Organizações 
Multiculturais [recurso eletrônico]. 2012

Portal Gestão: Teoria das Dimensões Culturais - Geert Hofsted. Disponivel em: < https://www.portal-gestao.com/artigos/6675-teoria-das-dimens\%C3\%B5esculturais-geert-hofstede.html> Acesso em: 12 de maio de 2018.

RICHARDSON, R. J. et al. Pesquisa social: métodos e técnicas. São Paulo: Atlas, 1985.

ROBBINS,Stephen P, Timothy A. Judge, Filipe Sobral; [tradução Rita de Cássia Gomes] - Comportamento Organizacional - $14^{\text {a }}$ e.d - São Paulo: Pearson Prentice Hall, 2010.

SÁ LEITÃO, Jaqueline. Relações entre clima organizacional \& transferência de treinamento. Dissertação. Brasília, UnB, 1995

SILVA, Edna Lúcia da; MENEZES, Estera Muszakat. Metodologia da pesquisa e elaboração de dissertação. Florianópolis: Laboratório de Ensino à Distância da UFSC, 2000.

VECCHIO, Robert P. - Comportamento Organizacional: conceitos básicos São Paulo: Cengage Learning, 2015.

ZANELLI, J.; ANDRADE, J.; BASTOS, A. Psicologia, Organizações e Trabalho no Brasil. Ed. Artmed. Porto Alegre, 2007.

ZANELLI, J.; ANDRADE, J.; BASTOS, A. Psicologia, Organizações e Trabalho no Brasil. Ed. Artmed. Porto Alegre, 2009. 


\section{Anexo 1 - Questionário}

Olá! Gostaria de contar com a sua colaboração nesta pesquisa. Ela faz parte do meu trabalho de conclusão de curso em Administração de Empresas na PUC-RIO.

O objetivo dessa pesquisa é mensurar como culturas diferentes podem influenciar a cultura organizacional das empresas e, também, impactar na cultura pessoal do colaborador.

Esta pesquisa não tomará muito do seu tempo. Esta pesquisa será trabalhada com total anonimato dos participantes e não tem respostas corretas ou incorretas.

É necessário que dê a sua opinião sincera, pois assim contribuirá para o sucesso da pesquisa.

Agradeço muito por sua participação.

1) Você trabalha em alguma empresa multinacional ou que sofreu fusão ou aquisição?

( ) Sim

2) Se respondeu sim especifique qual?

( ) Fusão

( ) Joint venture

( ) Aquisição

( ) Internacionalização da sua empresa

( ) Multinacional de outro país

( ) Outros:

3) Em qual?

Questão aberta

4) Há quanto tempo?

( ) menos de um ano

( ) 1 ano a 2 anos

( ) 2 a 3 anos

( ) 3 a 5 anos

( ) 5 a 8 anos

( ) mais de 8 anos 
5) Em que nível atua em sua organização?
( ) Operacional
( ) Tático
( ) Estratégico

6) Qual sua escolaridade?
( ) Fundamental
( ) Médio
( ) Superior
( ) Pós-graduação
( ) Mestrado
( ) Doutorado
( ) Outros:

7) Qual é seu cargo na organização?

( ) Estagiário

( ) Assistente de área (nível escolar médio)

( ) Analista de área (nível escolar superior)

( ) Gerente de área

( ) Diretor

( ) Outros:

8) Em qual área você trabalha na organização?
( ) $\mathrm{RH}$
( ) Financeiro
( ) Marketing
( ) Comercial
( ) Produção
( ) Outros:

9) Quantos anos você tem?
( ) até 20 anos
( ) $21-25$
( ) $26-30$
( ) $31-40$
( ) $41-50$
( ) Acima de 50 anos

10) Qual seu gênero?
( ) Feminino
( )Masculino
( )Outros 
11) Qual foi a principal diferença que você notou em relação á sua cultura (pessoal ou entre empresas?)?

(Destaque as 3 principais, 1 para a maior e 3 para a menor)

( )Prazos não flexíveis

( ) Pontualidade rígida

( ) Formalidade no tratamento pessoal

( ) Preponderância do elemento masculino

( ) Comunicação

( ) Objetividade

( ) Normatização

( ) Padronização

( ) Meritocracia

( ) Estilo gerencial

( ) Outros:

12) Você acha que diversidade é algo presente na cultura da organização?

( ) Nenhuma diversidade

( ) Pouca diversidade

( ) Razoavelmente diversificada

( ) Bastante diversificada

( ) Totalmente diversificada

13) Como você percebe que sua empresa lida com a diversidade cultural?

( )Muito bem

( )Bem

( )Razoavelmente

( )Mal

( )Muito mal

14) Quais impactos você percebe que a diversidade gera na organização?

Marque os 5 pontos que considerem que mais impacta na organização. 1 para o que mais impacta e 5 para o que menos impacta.

( ) Criatividade

( ) Integração entre as áreas

( ) Produtividade

( ) Motivação

( ) Ambiente Harmônico de trabalho

( ) Riqueza intelectual e cultural

( ) lgualdade de oportunidades

( ) Boa reputação no quesito de empregabilidade

( ) Identificação de clientes com perfis variados

( ) Liberdade de decisão

( ) Estilo de gestão....

( ) Reconhecimento sobre a importância dos empregados

( ) Inovação...

( ) Tecnologia 
( ) Outros:

15) Como você avalia o clima da organização em que trabalha?

( )Muito ruim

( ) Clima ruim

( ) Clima razoavel

( ) Clima agradavel

( ) Clima excelente

16) Quais são as ações do departamento de Recursos Humanos para aproximar os colaboradores de culturas organizacionais diferentes? (Marque os 3 principais pontos que você considera as principais ações)

( ) Comunicação interna para aproximar os colaboradores

( ) Festa interna de aniversariante do mês

( ) Mural de apresentação de colaboradores

( ) Eventos de final de ano com os colaboradores

( ) Visita de apresentação da empresa aos novos colaboradores

( ) E-mail interno apresentando novos colaboradores

( ) Ginastica laboral com colaboradores de diversas áreas

( ) Rede social corporativa

( ) Ações sociais com colaboradores de diversas áreas

( ) Festas internas para datas comemorativas

( ) Videoconferência com equipes de outros países para troca de experiências

( ) Comemoração pelas metas alcançadas

( ) Rotatividade de pessoas entre os departamentos e setores

( ) Outros:

17) $\mathrm{O} R H$ da sua organização estimula os colaboradores a darem suas opiniões quando não se sentem confortáveis em relação ao choque de cultura?

( ) Totalmente confortável para opinar, o RH da minha organização é bem acessivel 
( ) Sim, porém apenas de maneira formal através de pesquisas gerenciadas pelo $\mathrm{RH}$

( ) Eventualmente e em casos específicos que estejam normatizados.

( ) Não me sinto muito confortável para opinar junto ao $\mathrm{RH}$

( ) O RH não é acessível às opiniões dos empregados em geral.

18) Como o departamento de $\mathrm{RH}$ lida com as mudanças organizacionais?

( ) Medidas que não impactam em nada

( ) Medidas que não impactam muito

( ) Medidas razoaveis

( ) Tomam boas medidas

( ) Tomam excelentes medidas

19 ) Como são feitos os comunidados de mudanças na organização? (Selecione as 3 mais praticadas por ordem de 1 a 3 )

( ) Comunicados feitos via intranet (e-mails,comunidados e avisos)

( ) Reuniões periodicas

( ) Quadros de aviso

( ) Os colaboradores descobrem por si mesmos.

( ) Videoconferência

( ) Relatórios

( ) Jornal Interno

( ) Rádio Corporativo

( ) Eventos internos

( ) Canal Corporativo

( ) Outros:

20) O quanto a cultura da organização influenciou a sua cultura pessoal?

( ) Nenhuma influência

( ) Pouca influência

( ) Razoavel influência

( ) Considerável inflência

( ) Forte influência 
21) O quanto você sente que influenciou/influencia a cultura da sua organização?
( ) Nenhuma influência
( ) Pouca influência
( ) Razoavel influência
( ) Considerável inflência
( ) Forte influência

22) Quais os 3 pontos mais positivos da cultura do país de origem das organizações são trazidos por elas?
(1 para o mais e 3 para o menos importante)
( ) Formalidade
( ) Nacionalismo
( ) Firmeza
( ) Frieza
( ) Técnologia
( ) Ênfase no planejamento a longo prazo
( ) Não são receptivos a estrangueiros
( ) Criatividade
( ) Individualismo
( ) Foco no desempenho
( ) Outros

23) Quais os da nossa cultura eles mais apreciam?

(1 para o mais e 3 para o menos importante)

( ) Paternalismo

( ) Ênfase nas relaçãos pessoais

( ) Flexibilidade

( ) Rapidez

( ) Improvisação

( ) Hospitalidade

( ) Receptividade a outras raças

( ) Gosto pelo que vem de foras

( ) Importação de técnicas

( ) Ênfase no planejamento a curto prazo

( ) Outros: 


\section{Anexo 2 - Empresas participantes}

\begin{tabular}{l|l}
\hline 3) Em qual empresa? & $\mathbf{1}$ \\
\hline Accor Hotels & 1 \\
AES Atimus & 1 \\
Airswift & 1 \\
Aisin Seiki & 1 \\
Anonimo & 1 \\
Bayer & 1 \\
Belfan - P\&G & 1 \\
BHGE & 1 \\
Burguer King & 1 \\
Carrefour & 1 \\
Claro & 1 \\
Climate Policy Initiative & 1 \\
Colégio Evangélico de Maringá & 1 \\
Colgate - Palmolive & 1 \\
Continental Automative & 1 \\
Cruz Vermelha & 1 \\
Faculdades Católicas & 1 \\
Gefco Logistica Brasil & 1 \\
Global Home Group & 1 \\
GSK & 1 \\
Hacco & 1 \\
Hartmann & 1 \\
HP & 1 \\
Leo Learning & 1 \\
\hline Pony & 1 \\
\hline
\end{tabular}




\begin{tabular}{|c|c|}
\hline Red Bull & 1 \\
\hline Schlumberger & 1 \\
\hline Shell & 1 \\
\hline Statoil & 1 \\
\hline Stone & 1 \\
\hline Teekay & 1 \\
\hline TMF Group & 2 \\
\hline Upwork & 1 \\
\hline Vale & 1 \\
\hline Webedia & 1 \\
\hline Westinghose Eletric Company & 1 \\
\hline Xerox & 1 \\
\hline Heineken & 2 \\
\hline Loreal & 2 \\
\hline Petrobras & 2 \\
\hline PUC & 2 \\
\hline Techinp & 2 \\
\hline Accenture & 3 \\
\hline Tim & 4 \\
\hline Chevron & 4 \\
\hline Club Med & \\
\hline SC Johnson & 4 \\
\hline IBM & 5 \\
\hline Santander & 5 \\
\hline AMBEV & 8 \\
\hline Bioagri & 7 \\
\hline Servier & 15 \\
\hline
\end{tabular}


